\title{
Higher Order $\pi$-Conjugated Polycyclic Hydrocarbons with Open-shell Singlet Ground State: Nonazethrene versus Nonacene
}

\author{
Rui Huang, ${ }^{\dagger,+}$ Hoa Phan,,$^{\dagger}$ Tun Seng Herng, ${ }^{\S}$ Pan Hu, Wangdong Zeng, ${ }^{\dagger}$ Shao-qiang Dong, ${ }^{\dagger}$ \\ Soumyajit Das, ${ }^{\dagger}$ Yongjia Shen, ${ }^{\dagger}$ Jun Ding, ${ }^{\S}$ David Casanova, ${ }^{*} / \|$ and Jishan Wu ${ }^{* \dagger, \perp}$
}

${ }^{\dagger}$ Department of Chemistry, National University of Singapore, Science Drive 3, 117543, Singapore

*Key laboratory of Advanced Material, Department of Chemistry, East China University of Science and Technology, 130 Meilong Road, Shanghai, 200237, China

${ }^{\S}$ Department of Materials Science and Engineering, National University of Singapore, 119260, Singapore

|IKERBASQUE - Basque Foundation for Science \& Donostia International Physics Center \& Kimika Fakultatea, Euskal Herriko Unibertsitatea, Paseo Manuel de Lardizabal, 4, 20018 Donostia-San Sebastián, Euskadi, Spain

${ }^{\perp}$ Institute of Materials Research and Engineering, A STAR, 2 Fusionopolis Way, Innovis, \#08-03, 138634, Singapore

\section{Table of Content}

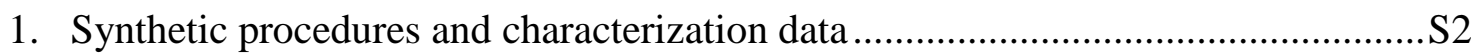

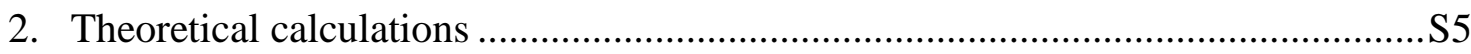

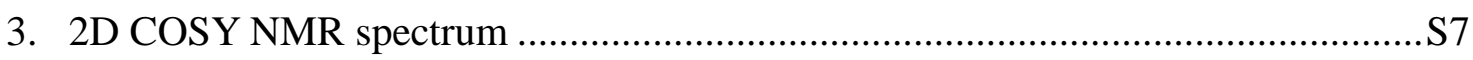

4. Differential pulse voltammogram of HR-NZ ................................................S8

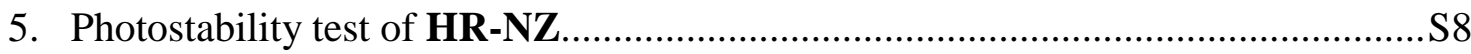

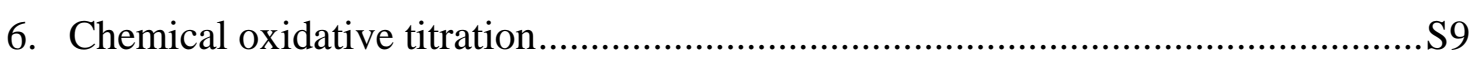

7. Appendix: NMR spectra and HR mass spectra of all new compounds .................S10

8. References....................................................... 23 


\section{Synthetic procedures and characterization data}

All reagents were purchased from commercial suppliers without further purification. Anhydrous dichloromethane (DCM) was distilled from $\mathrm{CaH}_{2}$. Anhydrous tetrahydrofuran (THF) was distilled from sodium-benzophenone prior to use. (2-methylnaphthalen-1-yl) boronic acid was prepared according our previous work (Y. Li et al., J. Am. Chem. Soc., 2012, 134, 14913).

${ }^{1} \mathrm{H}$ NMR and ${ }^{13} \mathrm{C}$ NMR spectra were recorded on Bruker DPX 300/400/500 NMR spectrometers with tetramethylsilane as internal standard. High resolution APCI mass spectra were recorded on a Bruker amazonX instrument. VT NMR and COSY NMR were recorded on Bruker DPX 500 NMR spectrometer. MALDI-TOF mass spectrum was recorded on a Bruker Autoflex instrument using anthracene-1, 8, 9-triol as matrix. UV-Vis absorption spectra were recorded on a Shimadzu UV-1700 and UV-3600 spectrometer. The electrochemical measurements were carried out in anhydrous DCM at room temperature under protection of nitrogen. ESR spectroscopy measurement was conducted on JEOL (FA200) spectrometer. Cyclic voltammetry measurements were performed in dry THF on a CHI 620C electrochemical analyser with a three-electrode cell, using $0.1 \mathrm{M} \mathrm{Bu}_{4} \mathrm{NPF}_{6}$ as supporting electrolyte, $\mathrm{AgCl} / \mathrm{Ag}$ as reference electrode, gold disk as working electrode, $\mathrm{Pt}$ wire as counter electrode, and scan rate at $50 \mathrm{mV} / \mathrm{s}$.

A Quantum Design 7 Tesla SQUID-VSM system was available for the magnetic measurements in this work. Powder sample with a weight of 5-10 mg was sealed in a plastic capsule. The magnetic susceptibility was measured in the temperature range of 2 to $380 \mathrm{~K}$ with an applied field of $0.5 \mathrm{~T}$. After correction of diamagnetic contributions from the sample, using tabulated constants, ${ }^{1}$ sample holder and paramagnetic contamination, the magnetic data were fitted with Bleaney-Bowers equation. ${ }^{2}$

Compound 1 (2,6-dimethoxy-9,10-anthraquinone). To the mixture of $\mathrm{K}_{2} \mathrm{CO}_{3}(11.6 \mathrm{~g}$, $84 \mathrm{mmol})$ dispersed in dry acetone $(200 \mathrm{~mL})$, anthraflavic acid $(5.0 \mathrm{~g}, 20.8 \mathrm{mmol})$ was added in one portion. The solution was heated to reflux and dimethyl sulfate $(5 \mathrm{ml}, 52 \mathrm{mmol})$ was added for further 3 days stirring. After cooling down to room temperature, the reaction was poured into water and the yellow solid precipitate was collected by filtration followed by washing by brine and ethanol, giving 5.02g crude product 1 in $90 \%$ yield. Compound 1 has very poor solubility and was used directly for next step without further purification. HR MS analysis (APCI) $\left[\mathrm{MH}^{+}\right]$: 269.0809, theoretical mass for $\mathrm{C}_{16} \mathrm{H}_{12} \mathrm{O}_{4}\left[\mathrm{MH}^{+}\right]$: 269.0808, err: -0.2 ppm.

Compound 2 (2,6-dimethoxy-9,10-dimesitylanthracene). To the solution of 2, 4, 6-trimethy-1-bromobenzene $(5.0 \mathrm{ml}, 32.7 \mathrm{mmol})$ in anhydrous $\mathrm{THF}(250 \mathrm{ml})$ at $-78{ }^{\circ} \mathrm{C}$, $n$-BuLi (2.0M in diethyl ester, $16 \mathrm{ml}, 32 \mathrm{mmol})$ was added dropwise under argon. The solution was stirred at $-78{ }^{\circ} \mathrm{C}$ for 1 hour and then compound $\mathbf{1}(2.68 \mathrm{~g}, 10 \mathrm{mmol})$ was added in one portion. The mixture was slowly warmed to room temperature and further stirred overnight. During this period, the suspension became transparent. The reaction was quenched by $\mathrm{HCl}$ $(2 \mathrm{M}, 10 \mathrm{ml})$ and then $\mathrm{SnCl}_{2}(19 \mathrm{~g}, 100 \mathrm{mmol})$ was added. The mixture was then heated to reflux for 5 hours. After cooling to room temperature, the reaction mixture was extracted by 
ethyl acetate and washed by brine. The organic layer was dried over anhydrous sodium sulfate. Upon evaporating off the solvent, the residue was washed by small amount of $\mathrm{MeOH}$, giving pure product as yellow solid $2(3.32 \mathrm{~g}, 70 \%) .{ }^{1} \mathrm{H}$ NMR $\left(300 \mathrm{MHz}, \mathrm{CDCl}_{3}\right): \delta \mathrm{ppm} 7.36$ $(\mathrm{d}, J=9.4 \mathrm{~Hz}, 2 \mathrm{H}), 7.09(\mathrm{~s}, 4 \mathrm{H}), 6.99\left(\mathrm{dd},{ }^{3} J=9.4,{ }^{4} J=2.5 \mathrm{~Hz}, 2 \mathrm{H}\right), 6.66(\mathrm{~d}, J=2.5 \mathrm{~Hz}, 2 \mathrm{H})$, $3.67(\mathrm{~s}, 6 \mathrm{H}), 2.45(\mathrm{~s}, 6 \mathrm{H}), 1.78(\mathrm{~s}, 12 \mathrm{H}) ;{ }^{13} \mathrm{C} \mathrm{NMR}\left(75 \mathrm{MHz}, \mathrm{CDCl}_{3}\right): \delta \mathrm{ppm} 156.52,137.45$, 136.84, 135.02, 133.32, 129.32, 128.27, 127.75, 126.72, 119.77, 102.45, 55.07, 21.26, 19.84; HR MS analysis (APCI) $\left[\mathrm{MH}^{+}\right]: 475.2628$, theoretical mass for $\mathrm{C}_{34} \mathrm{H}_{34} \mathrm{O}_{2}\left[\mathrm{MH}^{+}\right]: 475.2632$, err: $0.8 \mathrm{ppm}$.

Compound 3. To the solution of $2(3.1 \mathrm{~g}, 6.5 \mathrm{mmol})$ and TMEDA $(5 \mathrm{ml}, 33 \mathrm{mmol})$ in anhydrous THF $(250 \mathrm{ml})$ at $0{ }^{\circ} \mathrm{C}, n$-BuLi $(2.0 \mathrm{M}$ in diethyl ester, $13 \mathrm{ml}, 26 \mathrm{mmol})$ was added dropwise under argon. The solution was then further stirred at $0{ }^{\circ} \mathrm{C}$ for 5 hours and then anhydrous DMF $(2 \mathrm{ml}, 26.7 \mathrm{mmol})$ was added. 2 hours later, the reaction was quenched by $\mathrm{NH}_{4} \mathrm{Cl}$ aqueous solution. The organic layer was extracted with ethyl acetate and dried over anhydrous sodium sulfate. The solvent was removed under vacuum and the residue was purified by column chromatography (silica, hexane: DCM=2:5) to give a red solid 3 (450mg, 13\%). ${ }^{1} \mathrm{H}$ NMR (500 MHz, $\left.\mathrm{CDCl}_{3}\right): \delta \mathrm{ppm} 10.43(\mathrm{~s}, 2 \mathrm{H}), 8.01(\mathrm{~s}, 2 \mathrm{H}), 7.10(\mathrm{~s}, 4 \mathrm{H}), 6.74$ (s, $2 \mathrm{H}), 3.75(\mathrm{~s}, 6 \mathrm{H}), 2.46(\mathrm{~s}, 6 \mathrm{H}), 1.77(\mathrm{~s}, 12 \mathrm{H}) .{ }^{13} \mathrm{C}$ NMR $\left(75 \mathrm{MHz}, \mathrm{CDCl}_{3}\right) \delta 190.27,156.12$, 137.73, 137.16, 136.93, 133.33, 131.64, 130.88, 128.77, 127.67, 127.27, 103.52, 55.45, 21.28, 19.88. HR MS analysis (APCI) $\left[\mathrm{MH}^{+}\right]$: 531.2524, theoretical mass for $\mathrm{C}_{36} \mathrm{H}_{34} \mathrm{O}_{4}\left[\mathrm{MH}^{+}\right]$: 531.2530, err: 1.2 ppm.

Compound 4. To the solution of 3 (450mg, $0.85 \mathrm{mmol})$ in anhydrous DCM $(50 \mathrm{ml})$ at $0{ }^{\circ} \mathrm{C}$, $\mathrm{BBr}_{3}(0.3 \mathrm{ml}, 3.4 \mathrm{mmol})$ was added dropwise under argon. The solution was further stirred overnight and warmed up to room temperature. Water $(10 \mathrm{ml})$ was added to quench the reaction and the organic layer was dried over anhydrous sodium sulfate. The solvent was removed under vacuum and the residue was purified by column chromatography (silica, hexane: $\mathrm{DCM}=1: 1)$ to give a purple solid $4(235 \mathrm{mg}, 54 \%) .{ }^{1} \mathrm{H} \mathrm{NMR}\left(500 \mathrm{MHz}, \mathrm{CDCl}_{3}\right): \delta$ ppm $9.91(\mathrm{~s}, 2 \mathrm{H}), 7.90(\mathrm{~s}, 2 \mathrm{H}), 7.13(\mathrm{~s}, 4 \mathrm{H}), 6.92(\mathrm{~s}, 2 \mathrm{H}), 2.47(\mathrm{~s}, 6 \mathrm{H}), 1.78(\mathrm{~s}, 12 \mathrm{H}) .{ }^{13} \mathrm{C}$ NMR $\left(75 \mathrm{MHz}, \mathrm{CDCl}_{3}\right) \delta 196.97,153.59,138.33,138.09,137.16,137.05,133.06,131.70$, $128.79,127.63,124.93,109.32,21.23,19.90$. HR MS analysis (APCI) $\left[\mathrm{MH}^{+}\right]: 503.2220$, theoretical mass for $\mathrm{C}_{34} \mathrm{H}_{30} \mathrm{O}_{4}\left[\mathrm{MH}^{+}\right]$: 503.2217, err: $-0.6 \mathrm{ppm}$.

Compound 5. To the solution of $4(235 \mathrm{mg}, 0.47 \mathrm{mmol})$ and pyridine $(0.4 \mathrm{ml}, 4.9 \mathrm{mmol})$ in anhydrous DCM $(50 \mathrm{ml})$ at $0{ }^{\circ} \mathrm{C}$, triflic anhydride $(0.25 \mathrm{ml}, 1.5 \mathrm{mmol})$ was added by drops under argon. The solution was then stirred at $0{ }^{\circ} \mathrm{C}$ for 2 hours. Water $(10 \mathrm{ml})$ was added to quench the reaction and the organic layer was dried over anhydrous sodium sulfate. The solvent was removed under vacuum and the residue was purified by column chromatography (silica, hexane: $\mathrm{DCM}=1: 1)$ to give a yellow solid $5(210 \mathrm{mg}, 58 \%) .{ }^{1} \mathrm{H} \mathrm{NMR}(300 \mathrm{MHz}$, $\left.\mathrm{CDCl}_{3}\right): \delta \mathrm{ppm} 10.11(\mathrm{~s}, 2 \mathrm{H}), 8.20(\mathrm{~s}, 2 \mathrm{H}), 7.50(\mathrm{~s}, 2 \mathrm{H}), 7.18(\mathrm{~s}, 4 \mathrm{H}), 2.50(\mathrm{~s}, 6 \mathrm{H}), 1.75(\mathrm{~s}$,

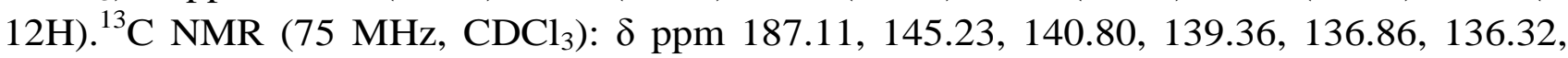
$131.77,130.88,129.95,129.16,128.54,120.52,21.26,19.93 .{ }^{19} \mathrm{~F} \mathrm{NMR}\left(282 \mathrm{MHz}, \mathrm{CDCl}_{3}\right)$ : $\delta \mathrm{ppm}-72.84$. HR MS analysis (APCI) $\left[\mathrm{MH}^{+}\right]: 767.1201$, theoretical mass for $\mathrm{C}_{36} \mathrm{H}_{28} \mathrm{~F}_{6} \mathrm{O}_{8} \mathrm{~S}_{2}$ $\left[\mathrm{MH}^{+}\right]:$767.1203, err: $0.2 \mathrm{ppm}$.

Compound 6. A mixture of 5 (200mg, 0.26mmol), (2-methylnaphthalen-1-yl) boronic acid (145mg, 0.78mmol), $\mathrm{Pd}\left(\mathrm{PPh}_{3}\right)_{4}$ (30mg, 0.026mmol), $\mathrm{Na}_{2} \mathrm{CO}_{3}(276 \mathrm{mg}, 2.0 \mathrm{mmol})$ in toluene $(10 \mathrm{ml}) /$ ethanol $(2 \mathrm{ml})$ /water $(2 \mathrm{ml})$ was degassed by three freeze-pump-thaw cycles and then 
heated to $95{ }^{\circ} \mathrm{C}$ for 2 days under argon. After cooling down, the mixture was poured into water and extracted with DCM. The organic layer was washed by brine and dried over anhydrous sodium sulfate. The solvent was removed under vacuum and the residue was purified by column chromatography (silica, hexane: DCM=1:1) to give a yellow solid 6 (121mg, 62\%). ${ }^{1} \mathrm{H}$ NMR (400 MHz, $\mathrm{CD}_{2} \mathrm{Cl}_{2}$ ): $\delta$ ppm $9.49(\mathrm{~s}, 2 \mathrm{H}), 8.27(\mathrm{~s}, 2 \mathrm{H}), 7.87-7.80(\mathrm{~m}$, 4H), $7.51(\mathrm{~s}, 2 \mathrm{H}), 7.40(\mathrm{~m}, 4 \mathrm{H}), 7.29(\mathrm{~m}, 2 \mathrm{H}), 7.22(\mathrm{~m}, 2 \mathrm{H}), 7.07(\mathrm{~m}, 4 \mathrm{H}), 2.35(\mathrm{~s}, 6 \mathrm{H}), 2.15$ $(\mathrm{m}, 6 \mathrm{H}), 1.86(\mathrm{~m}, 12 \mathrm{H}) .{ }^{13} \mathrm{C}$ NMR $\left(126 \mathrm{MHz}, \mathrm{CDCl}_{3}\right): \delta \mathrm{ppm} 191.90,139.49,137.95,136.94$, $136.87,136.68,134.28,133.77,133.60,133.41,132.87,131.76,130.41,129.89,129.59$, $128.92,128.75,128.42,128.09,128.04,126.48,125.47,125.11,21.16,20.90,20.23,20.20$, 20.12, 20.09. HRMS analysis (APCI) $\left[\mathrm{MH}^{+}\right]$: 751.3573 , theoretical mass for $\mathrm{C}_{56} \mathrm{H}_{46} \mathrm{O}_{2}\left[\mathrm{MH}^{+}\right]$: 751.3571, err: -0.3 ppm.

Compound 7. To the solution of $6(112 \mathrm{mg}, 0.15 \mathrm{mmol})$ in anhydrous $\mathrm{THF}(10 \mathrm{ml})$ at $0{ }^{\circ} \mathrm{C}$, 3,5-bis(trifluoromethyl) phenylmagnesium bromide (1M in THF, 1ml) was added dropwise under argon. The solution was then stirred overnight and quenched by water. The mixture was extracted by ethyl acetate and organic layer was dried over anhydrous sodium sulfate. The solvent was removed under vacuum and the residue was purified by column chromatography, collecting the product isomers as a mixture 7 (159mg, 90\%). Nominal MALDI-TOF Mass $\left[\mathrm{M}^{+}\right]$: $1177.808, \mathrm{C}_{72} \mathrm{H}_{54} \mathrm{~F}_{12} \mathrm{O}_{2}\left[\mathrm{M}^{+}\right]: 1178.3932$.

Compound 8. To the solution of mixture $7(159 \mathrm{mg}, 0.135 \mathrm{mmol})$ in anhydrous DCM (10 $\mathrm{ml})$ at $0{ }^{\circ} \mathrm{C}$, boron trifluoride-diethyl etherate and trifluoroacetic acid were added drop by drop under argon. The reaction was monitored by TLC. After the reaction finished, water (10ml) was added to quench the reaction. The organic layer was dried over anhydrous sodium sulfate. The solvent was removed under vacuum and the residue was purified by column chromatography (silica, hexane: $\mathrm{DCM}=1: 1)$ to give an isomeric yellow solid 8 (138mg, $89 \%)$. HRMS analysis (APCI) $\left[\mathrm{MH}^{+}\right]$: 1143.3799 , theoretical mass for $\mathrm{C}_{72} \mathrm{H}_{50} \mathrm{~F}_{12}\left[\mathrm{MH}^{+}\right]: 1143.3794$, err: -0.5 ppm.

HR-NZ. Precursor 8 (46mg, 0.04mmol), DDQ (18mg, 0.08mmol) were mixed and protected under argon. Degassed dry DCM (10ml) was added via syringe to dissolve the solid mixture. The solution immediately changed into dark red color and then, gradually became deep green. The reaction was further monitored by TLC for 1 hour and then stopped. The solvent was removed by vacuum and purified by flash column chromatography under argon protection (triethylamine treated silica, hexane: $\mathrm{DCM}=5: 1$ ). The crude product was then precipitated by $\mathrm{DCM} /$ acetonitrile in a glove box and filtered to give pure solid product $(9 \mathrm{mg}, 20 \%) .{ }^{1} \mathrm{H}$ NMR in aromatic zone $\left(500 \mathrm{MHz}, \mathrm{THF}_{\mathrm{d}}, 233 \mathrm{~K}\right): \delta \mathrm{ppm} 8.22(\mathrm{~s}, 2 \mathrm{H}), 7.96(\mathrm{~s}, 4 \mathrm{H}), 7.71(\mathrm{~d}$, $J=8.1 \mathrm{~Hz}, 2 \mathrm{H}), 7.62(\mathrm{~d}, J=7.5 \mathrm{~Hz}, 2 \mathrm{H}), 7.53(\mathrm{~s}, 2 \mathrm{H}), 7.42(\mathrm{~d}, J=8.0 \mathrm{~Hz}, 2 \mathrm{H}), 7.25(\mathrm{t}, J=$ $7.6 \mathrm{~Hz}, 2 \mathrm{H}), 6.89(\mathrm{~s}, 4 \mathrm{H}), 6.80(\mathrm{~d}, J=7.5 \mathrm{~Hz}, 2 \mathrm{H}), 5.94(\mathrm{~s}, 2 \mathrm{H})$. HRMS analysis (APCI) $\left[\mathrm{MH}^{+}\right]$: 1141.3630, theoretical mass for $\mathrm{C}_{72} \mathrm{H}_{48} \mathrm{~F}_{12}\left[\mathrm{MH}^{+}\right]$: 1141.3637, err: $0.6 \mathrm{ppm}$. 


\section{Theoretical calculations}

\subsection{Computational details}

Molecular geometries of HR-NZ and for the rest of molecular models explored in this work were optimized within the density functional theory framework and with the spin unrestricted version of the long-range corrected version of B3LYP energy functional (UCAM-B3LYP). ${ }^{3}$ Calculations of the ground state electronic structure and singlet-triplet energy gaps were done at three different levels: (i) UCAM-B3LYP, (ii) spin-flip (SF) time-dependent density functional theory (TDDFT) with the Tamm-Dancoff approximation (TDA) ${ }^{4}$ and the BHHLYP functional (50\% Hartree-Fock exchange + $50 \%$ Becke exchange ${ }^{5}+100 \%$ LYP correlation), ${ }^{6}$ i.e. SF-BHHLYP, ${ }^{7}$ and (iii) restricted active space spin-flip (RAS-SF). RAS-SF calculations were performed with the presence of hole and particle contributions using the lowest (HOMO-to-LUMO) triplet as the reference configuration and with 4 electrons in 4 orbitals in the RAS2 space. Carbon 1s core orbitals were frozen in the configuration interaction expansion of the wave function.

Calculations were performed with the 6-31G(d,p) basis set for all atoms. Geometry optimizations and electronic structure calculations at the UCAM-B3LYP level were performed with the Gaussian09 program suite, ${ }^{8}$ while RAS-SF and SF-BHHLYP calculations were done with the Q-Chem package. ${ }^{9}$

\subsection{Singlet-triplet gap and diradical character}

Here we present the singlet-triplet energy gaps and diradical characters computed at the UCAM-B3LYP and SF-BHHLYP levels (Table S1 and S2, respectively).

Table S1. Calculated diradical character $\left(y_{0}\right)$ and singlet-triplet energy gaps $\left(\Delta E_{\mathrm{S}-\mathrm{T}}\right.$ in $\left.\mathrm{kcal} / \mathrm{mol}\right)$ of parent acenes and zethrenes, HR-NZ and JA-NA at the UCAM-B3LYP/6-31G(d,p) level. HexA: hexacene, HepA: heptacene, OA: octacene, and NA: nonacene.

\begin{tabular}{lll|lll} 
Molecule & $y_{0}$ & $\Delta E_{\text {S-T }}$ & Molecule & $y_{0}$ & $\Delta E_{\text {S-T }}$ \\
Zth & 0 & -16.5 & HexA & 0.12 & -13.4 \\
HZ & 0.17 & -9.0 & HepA & 0.29 & -11.4 \\
OZ & 0.37 & -6.4 & OA & 0.44 & -11.1 \\
NZ & 0.50 & -5.6 & NA & 0.58 & -11.9 \\
HR-NZ & 0.48 & -5.5 & JA-NA & 0.61 & -13.3
\end{tabular}

Table S2. Calculated diradical character measured by the amplitude of the configuration with doubly occupied LUMO $\left(L^{2}\right)$ and singlet-triplet energy gaps $\left(\Delta E_{\mathrm{S}-\mathrm{T}}\right.$ in $\left.\mathrm{kcal} / \mathrm{mol}\right)$ of parent acenes and zethrenes, HR-NZ and JA-NA at the SF-BHHLYP/6-31G(d,p) level. HexA: hexacene, HepA: heptacene, OA: octacene, and NA: nonacene.

\begin{tabular}{lll|lll} 
Molecule & $L^{2}$ & $\Delta E_{\text {S-T }}$ & Molecule & $L^{2}$ & $\Delta E_{\text {S-T }}$ \\
Zth & 0.14 & -35.7 & HexA & 0.23 & -18.7 \\
HZ & 0.25 & -18.7 & HepA & 0.29 & -12.2 \\
OZ & 0.31 & -12.2 & OA & 0.36 & -8.5 \\
NZ & 0.34 & -9.6 & NA & 0.42 & -6.5 \\
HR-NZ & 0.34 & -9.5 & JA-NA & 0.43 & -6.5
\end{tabular}


The diradical character $y_{0}$ was calculated based on the occupation number of the LUNO according to Yamaguchi's scheme:

$$
y_{0}=1-\frac{2 T_{0}}{1+T_{0}^{2}} ; \quad T_{0}=\frac{n_{H O N O}-n_{L U N O}}{2}
$$

The calculated frontier orbital profiles and spin density distribution maps of higher order acenes and extended zethrenes are shown in Figure S1.

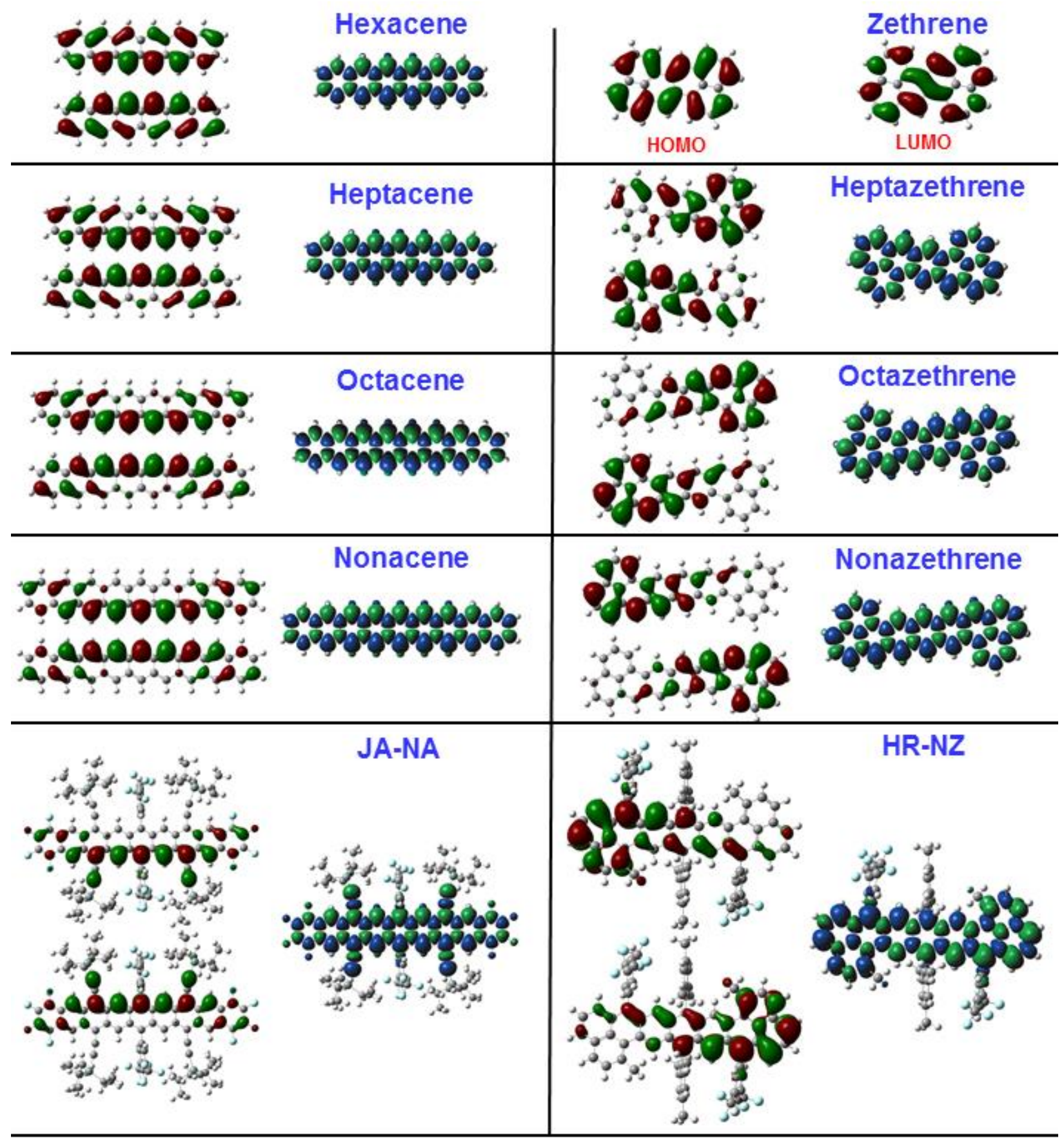

Figure S1. Calculated frontier molecular orbital (SOMO- $\alpha /-\beta)$ profiles and spin density maps for the singlet diradicals of all higher order acenes and the extended zethrenes. For zethrene, HOMO and LUMO profiles are shown. 


\subsection{Dependence of RAS2 space in RAS-SF calculations}

In other to explore the dependence of RAS-SF results with the size of the RAS2 space, we have computed RAS-SF singlet-triplet energy gaps with three different spaces, i.e. $n$ electrons in $n$ orbitals with $n=2,4$ and 6. Results show the same trends for the three orbital spaces (Figure S2).

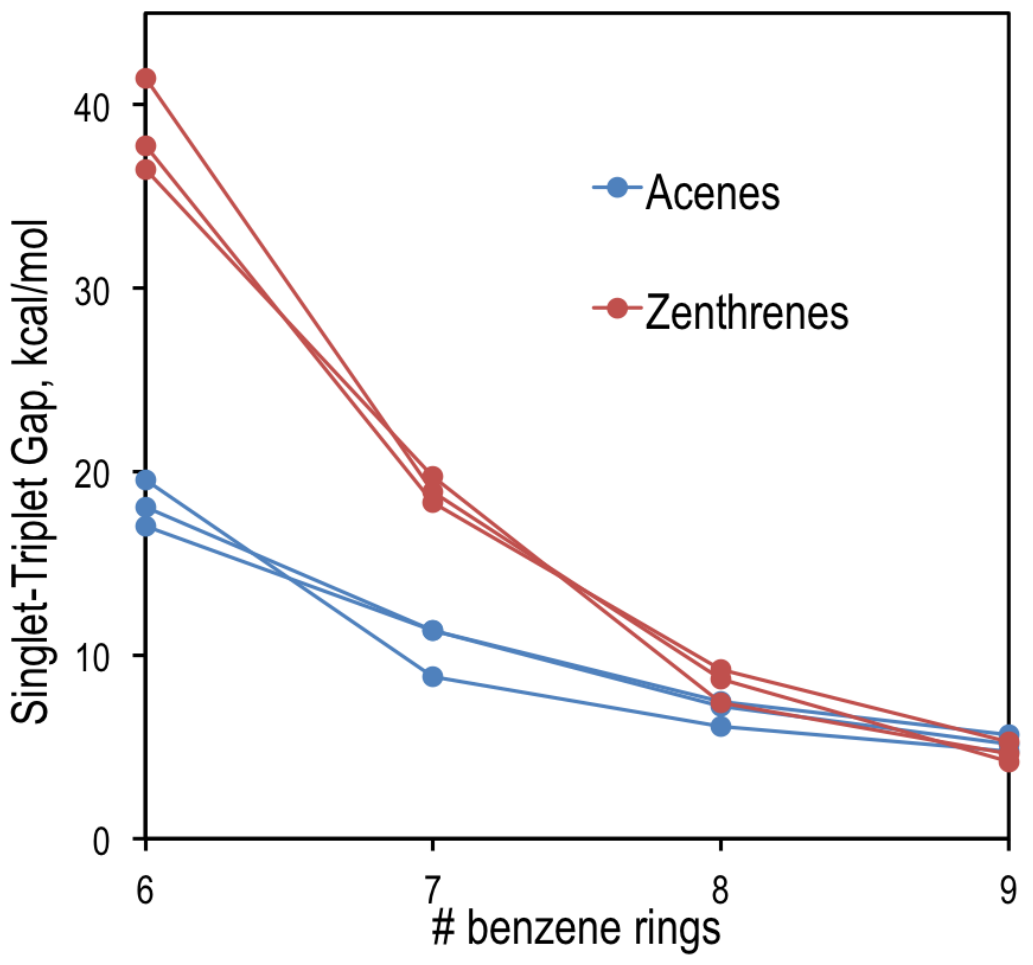

Figure S2. Singlet-triplet energy gaps (in $\mathrm{kcal} / \mathrm{mo}$ ) for the acene and zethrene series computed at the RAS-SF/6-31G(d,p) level with $(n, n)$ RAS2 spaces $(n=2,4$ and 6$)$.

\subsection{Quantification of charge resonances}

Charge resonance contributions where obtained at the RAS-SF with 2 electrons in 2 orbitals in the RAS2 space. The molecular orbital fragmentation and CR contributions were obtained following the scheme indicated elsewhere. ${ }^{10,11}$

\section{2D COSY NMR spectrum of HR-NZ}

$2 \mathrm{D}{ }^{1} \mathrm{H}-{ }^{1} \mathrm{H}$ COSY NMR spectrum was conducted in JY NMR tube in $d_{8}$-THF at $233 \mathrm{~K}$ with a very clear assignment in HR-NZ structure.

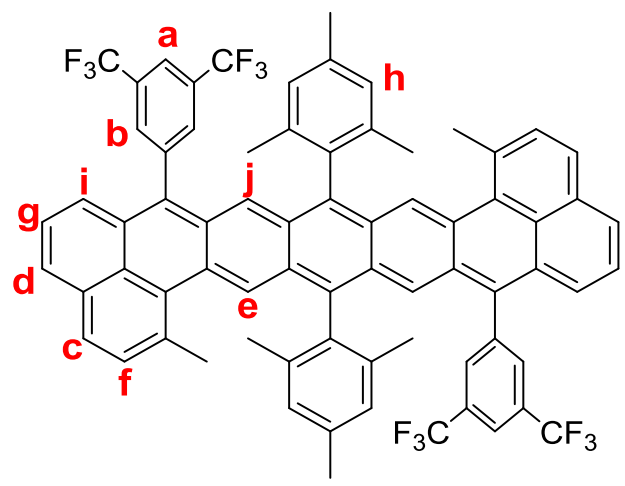




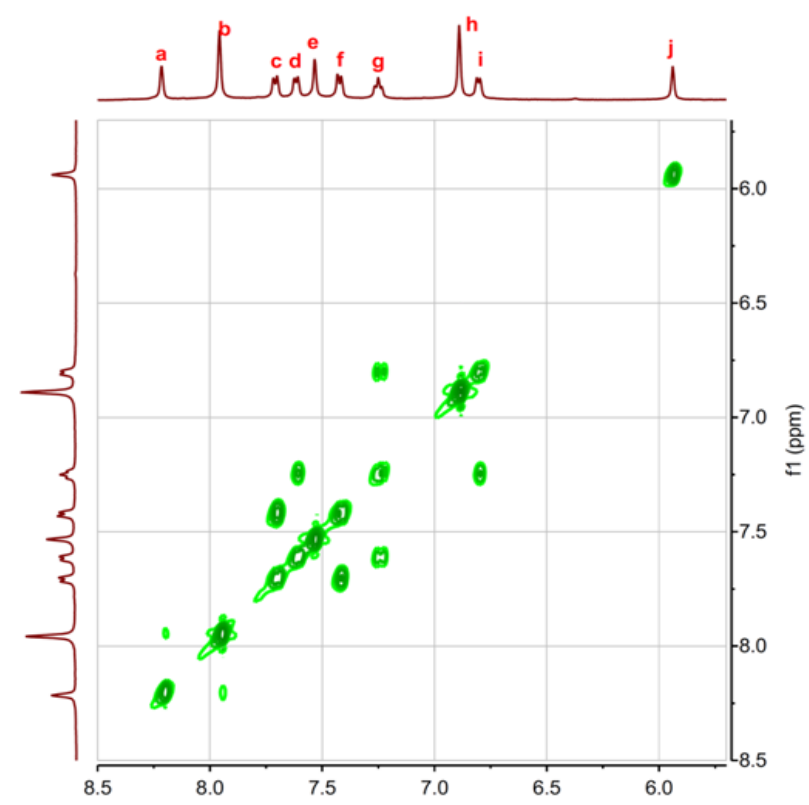

Figure S3. 2D COSY NMR spectrum (in the aromatic region) of HR-NZ in THF- $d_{8}$ at $233 \mathrm{~K}$.

\section{Differential pulse voltammogramof HR-NZ}

The electrochemical measurements were carried out in anhydrous DCM at room temperature under protection of nitrogen. 0.1 $\mathrm{M} \mathrm{BuNPF}_{6}$ as supporting electrolyte, $\mathrm{Ag} / \mathrm{AgCl}$ as reference electrode, $\mathrm{Au}$ disk as working electrode, $\mathrm{Pt}$ wire as counter electrode, and scan rate at $50 \mathrm{mV} / \mathrm{s}$. The potential was externally calibrated by $\mathrm{Fc}^{+} / \mathrm{Fc}$ couple.

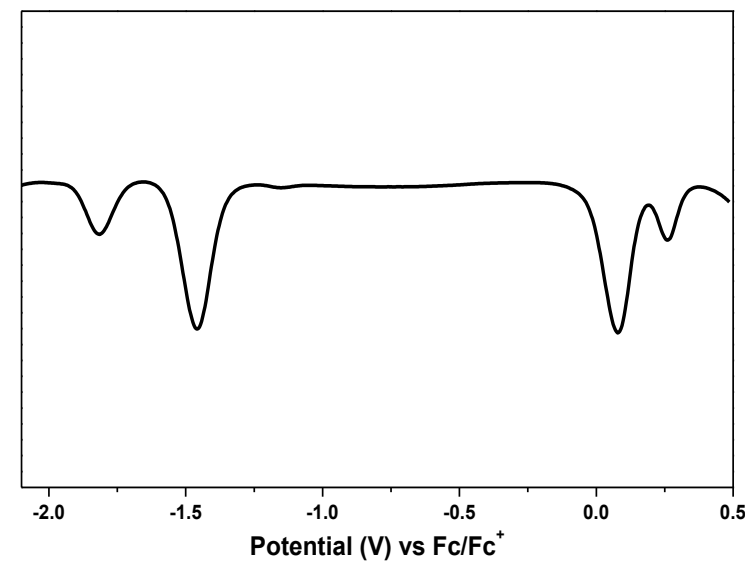

Figure S4. Differential pulse voltammogram of HR-NZ in DCM.

\section{Photostability test of HR-NZ}

During photostability test, the solution of HR-NZ in anhydrous DCM was exposed to an ambient air / light at room temperature. The solution of HR-NZ was graduation decomposed with a clear sign of decrease in optical intensity. The half life time of HR-NZ was around 16 hours by plotting the absorption intensity at $672 \mathrm{~nm}$ with time. 

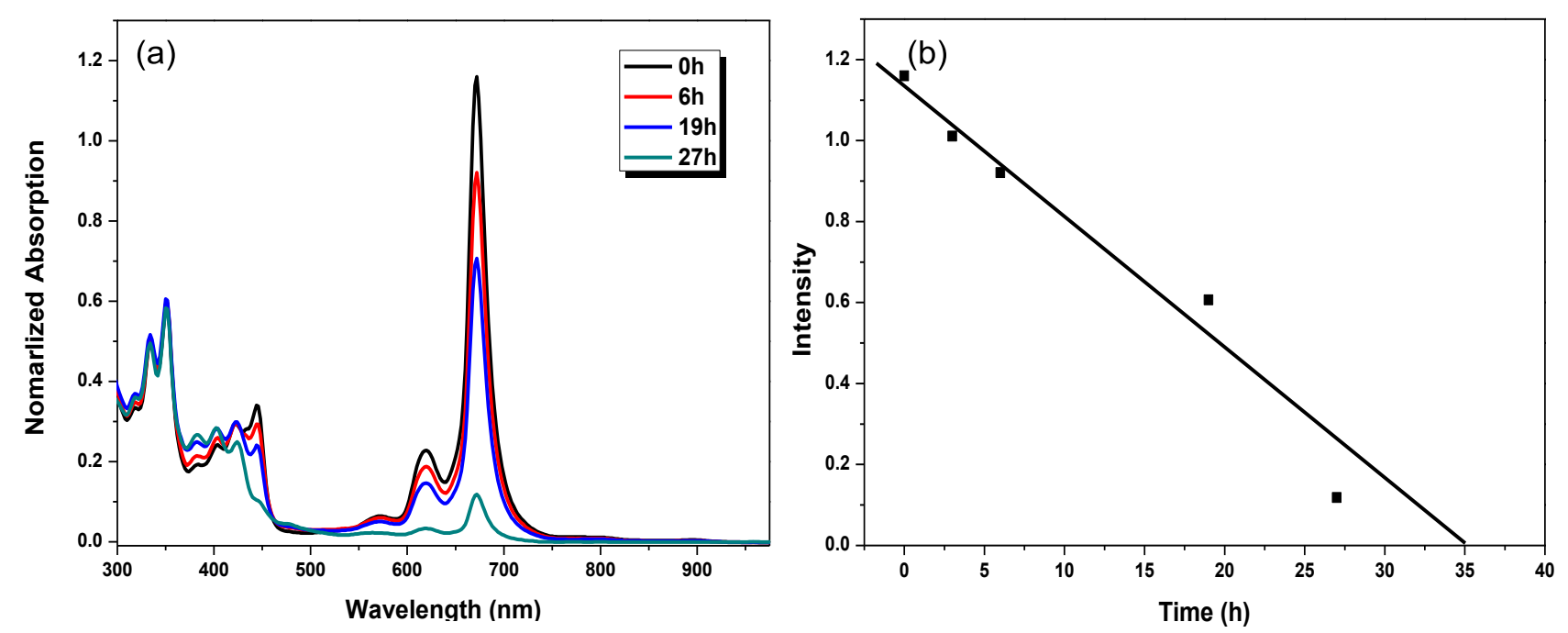

Figure S5. (a) Change of the absorption spectrum of HR-NZ in DCM with time under ambient air and light conditions; (b) the decay curve of the optical density at $672 \mathrm{~nm}$.

\section{Chemical oxidative titration of HR-NZ}
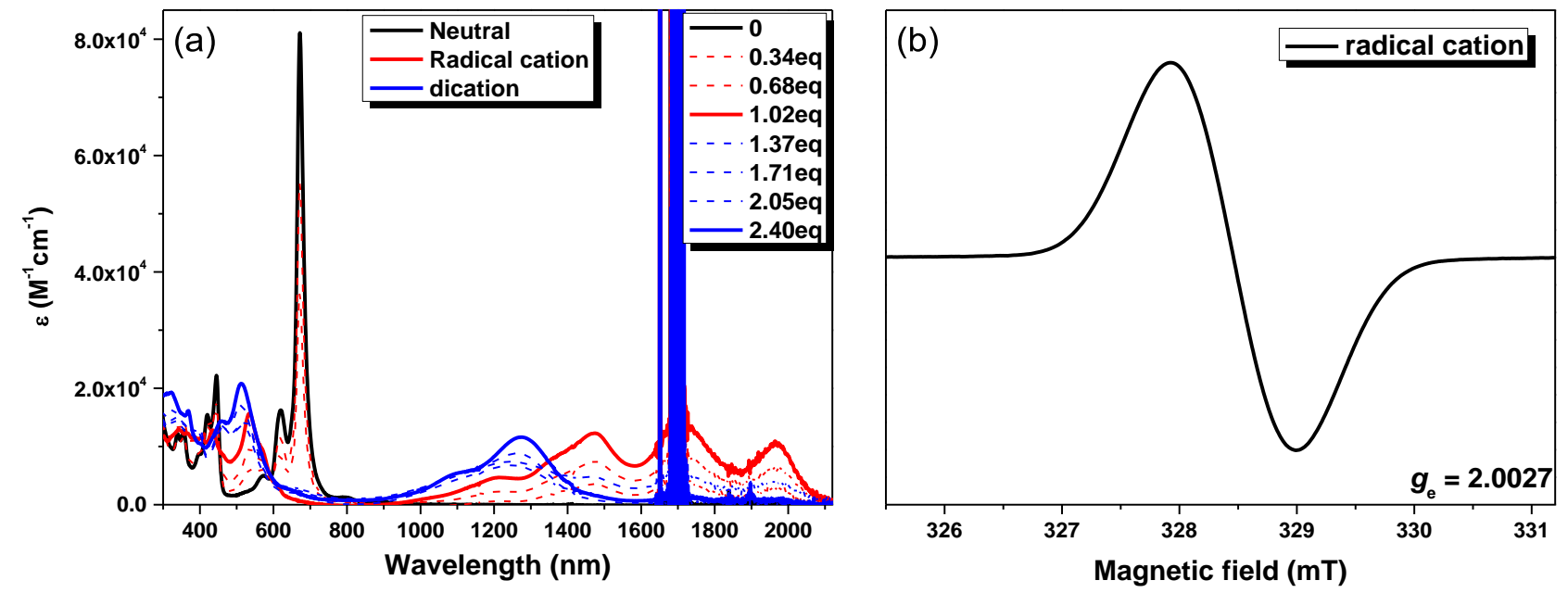

Figure S6. (a) UV-vis-NIR absorption spectra of HR-NZ in DCM upon addition of different amount of oxidant $\mathrm{NO} \cdot \mathrm{SbF}_{6}$ in acetonitrile; (b) ESR spectrum of the in situ generated radical cation at room temperature. 
7. Appendix: NMR spectra and HR mass spectra of new intermediates

\section{Mass Spectrum SmartFormula Report}

\section{Analysis Info}

Analysis Name Method

Sample Name

Comment
D:IDatalChemistry\2015 Samplel201601\0122\268-1.d $\mathrm{YCH}-150-1800 . \mathrm{m}$

268

A/P Wu Jishan
Acquisition Date $\quad$ 1/22/2016 1:29:01 PM

Operator default user

Instrument / Ser\# micrOTOF-Q II 10269

Acquisition Parameter

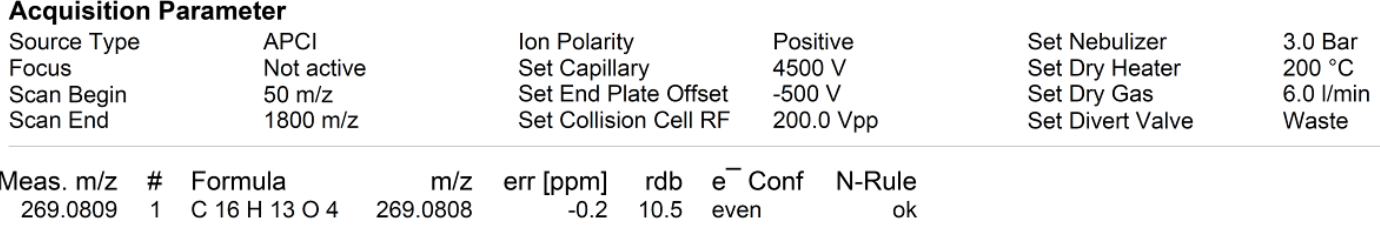

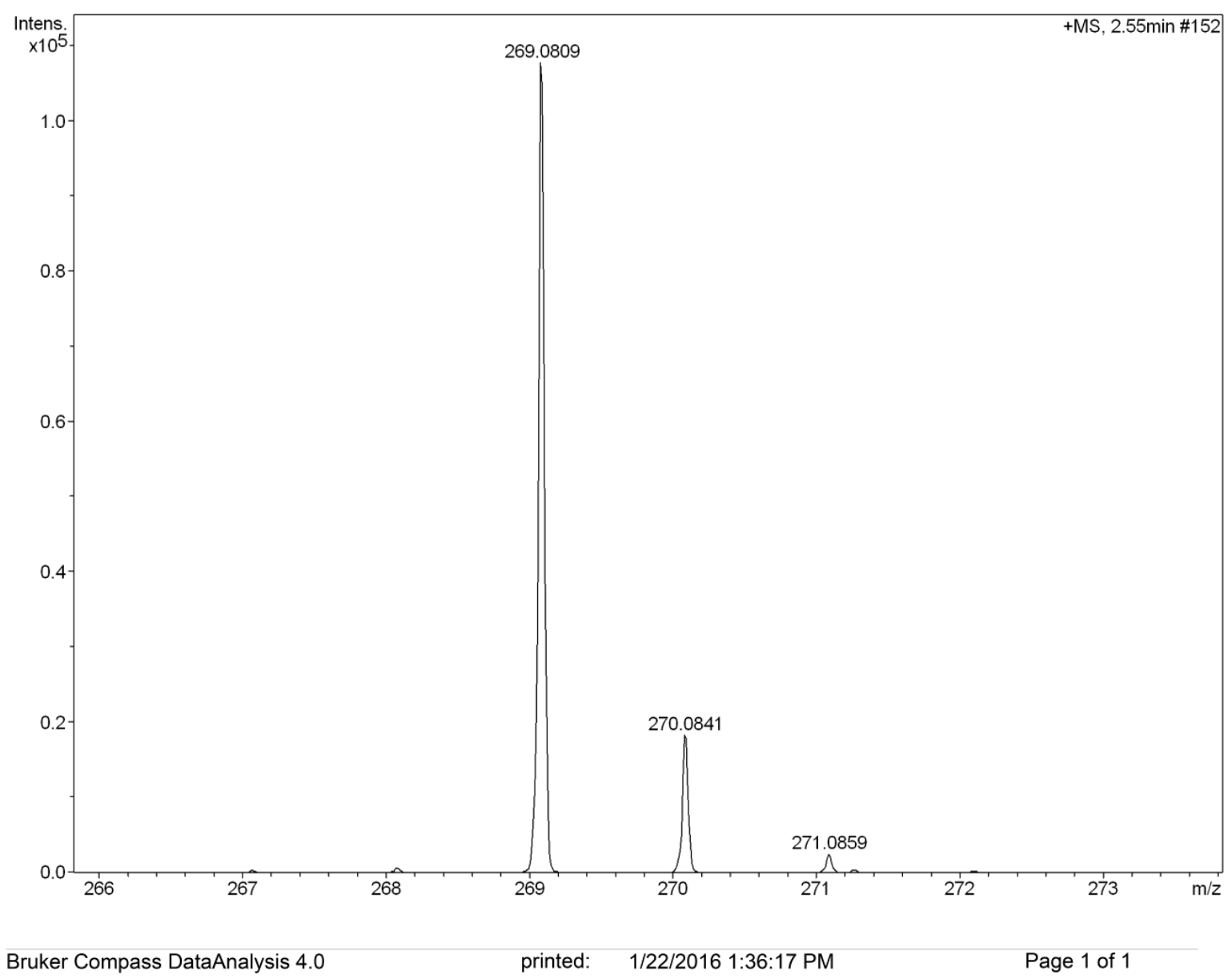

Figure S7. HR APCI mass spectrum of compound $\mathbf{1}$ 


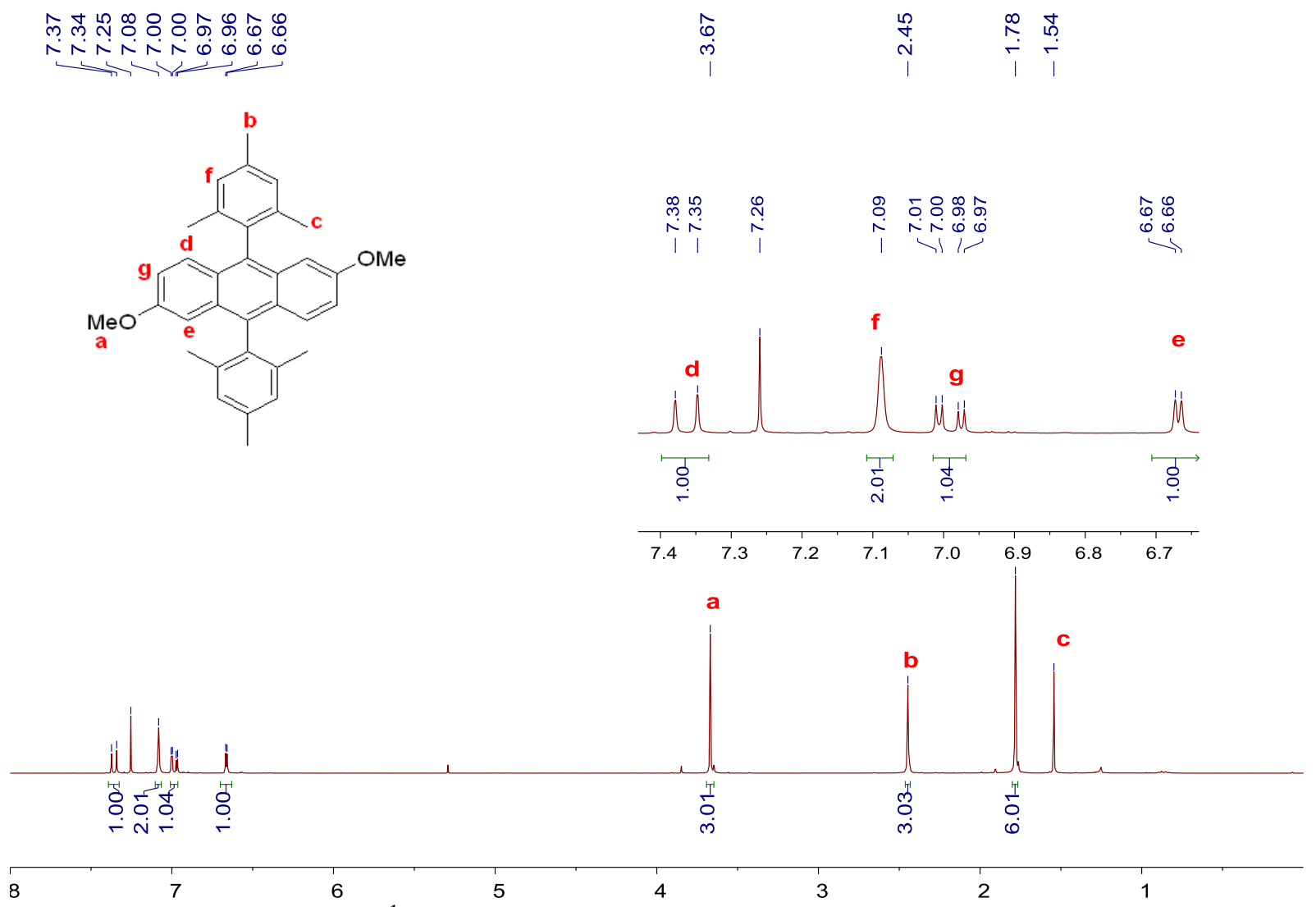

Figure S8. ${ }^{1} \mathrm{H}$ NMR spectrum of compound $2\left(\mathrm{CDCl}_{3}, \mathrm{rt}\right)$.
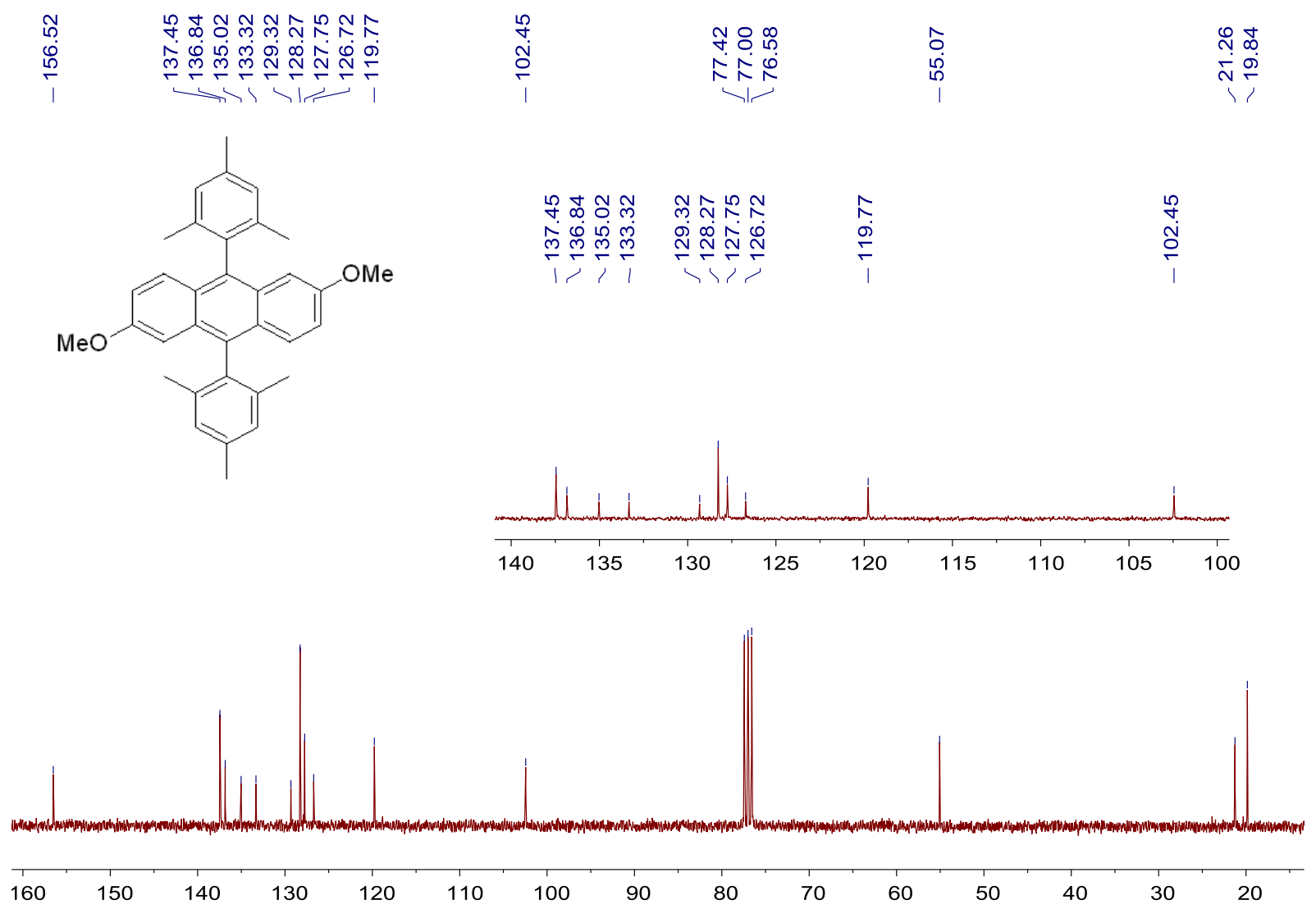

Figure S9. ${ }^{1} \mathrm{H}$ NMR spectrum of compound $2\left(\mathrm{CDCl}_{3}, \mathrm{rt}\right)$. 


\section{Mass Spectrum SmartFormula Report}

\section{Analysis Info}

Analysis Name

Method

Sample Name

Comment
Acquisition Date $\quad 1 / 22 / 2016$ 1:36:53 PM

Operator

default user

YCH-150-1800.m

Instrument / Ser\# micrOTOF-Q || 10269

A/P Wu Jishan

Acquisition Parameter

$\mathrm{APCl}$

Focus Not active

Scan Begin $\quad 50 \mathrm{~m} / \mathrm{z}$

Scan End

$50 \mathrm{~m} / \mathrm{z}$

Ion Polarity

Positive

$4500 \mathrm{~V}$

Offset $\quad-500 \mathrm{~V}$ Set Collision Cell RF $\quad 200.0$ Vpp

$\begin{array}{ll}\text { Set Nebulizer } & 3.0 \mathrm{Bar} \\ \text { Set Dry Heater } & 200^{\circ} \mathrm{C} \\ \text { Set Dry Gas } & 6.0 \mathrm{l} / \mathrm{min} \\ \text { Set Divert Valve } & \text { Waste }\end{array}$

Meas. $\mathrm{m} / \mathrm{z}$ \# Formula $\mathrm{m} / \mathrm{z}$ err [ppm] rdb e-Conf N-Rule

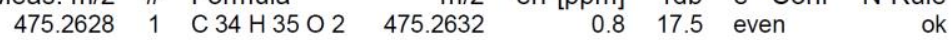

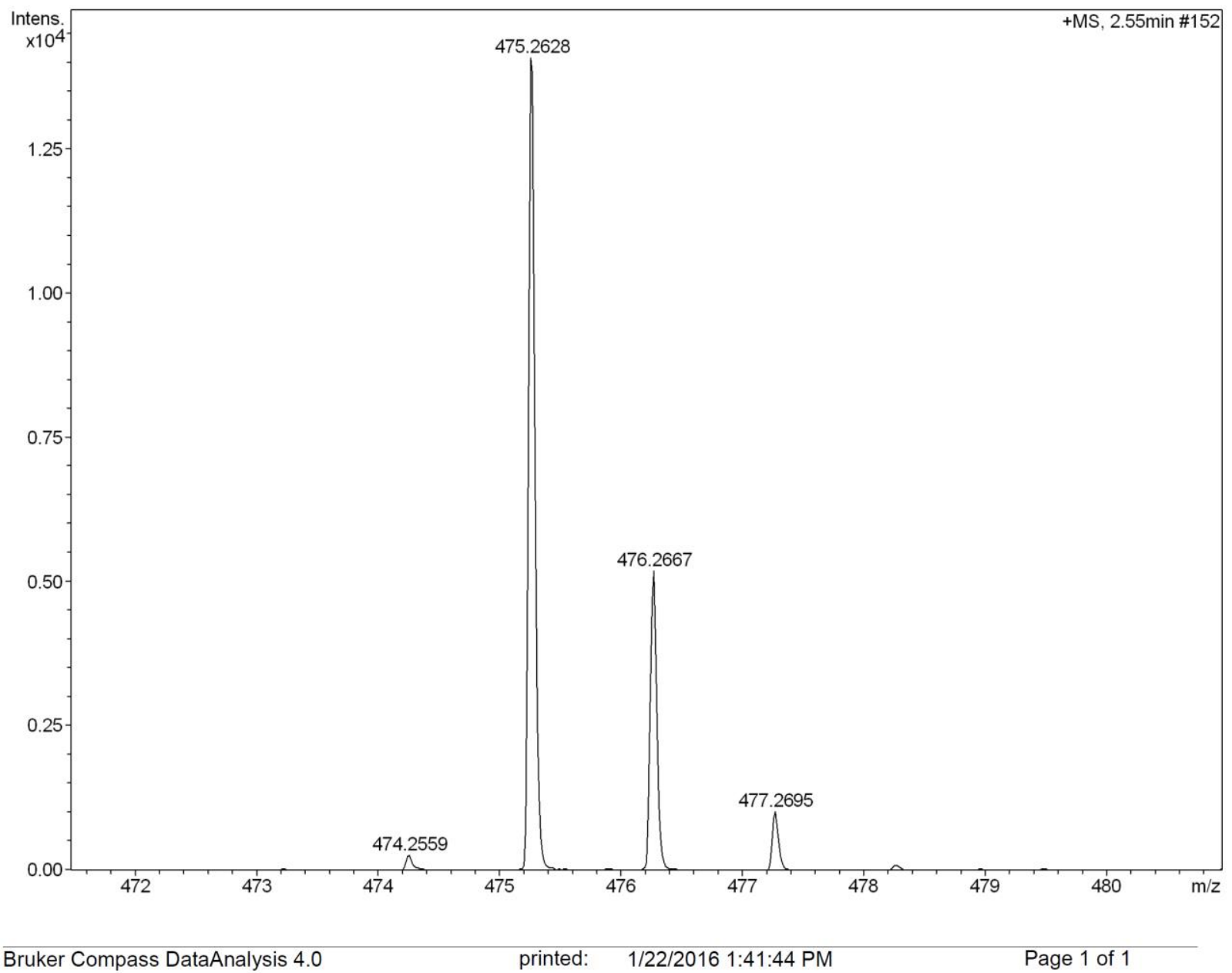

Figure S10. HR APCI mass spectrum of compound 2. 

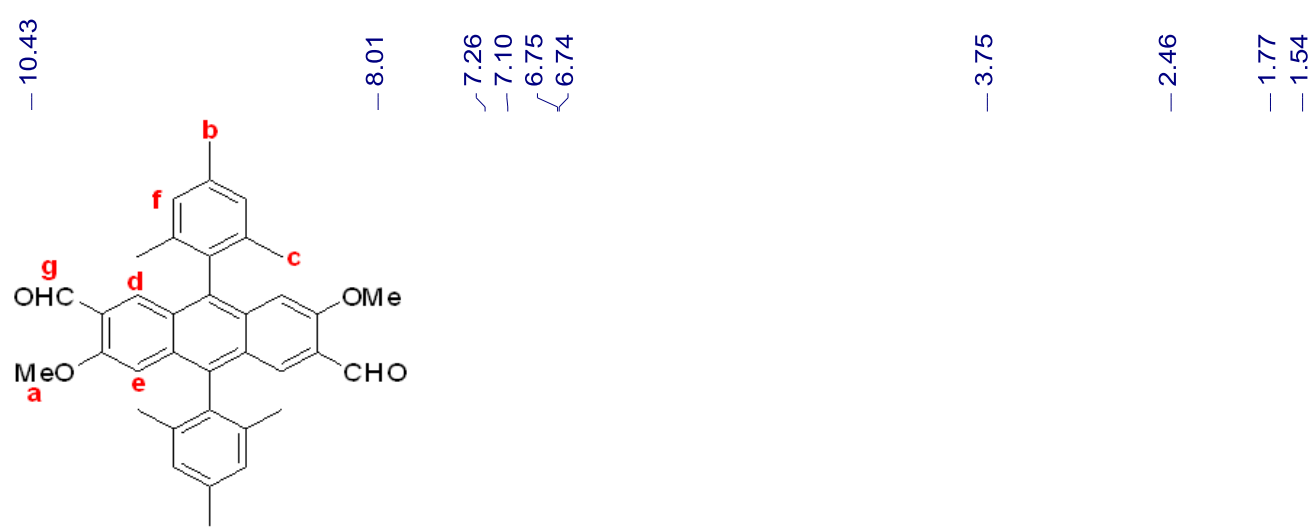

Exact Mass: 530.2

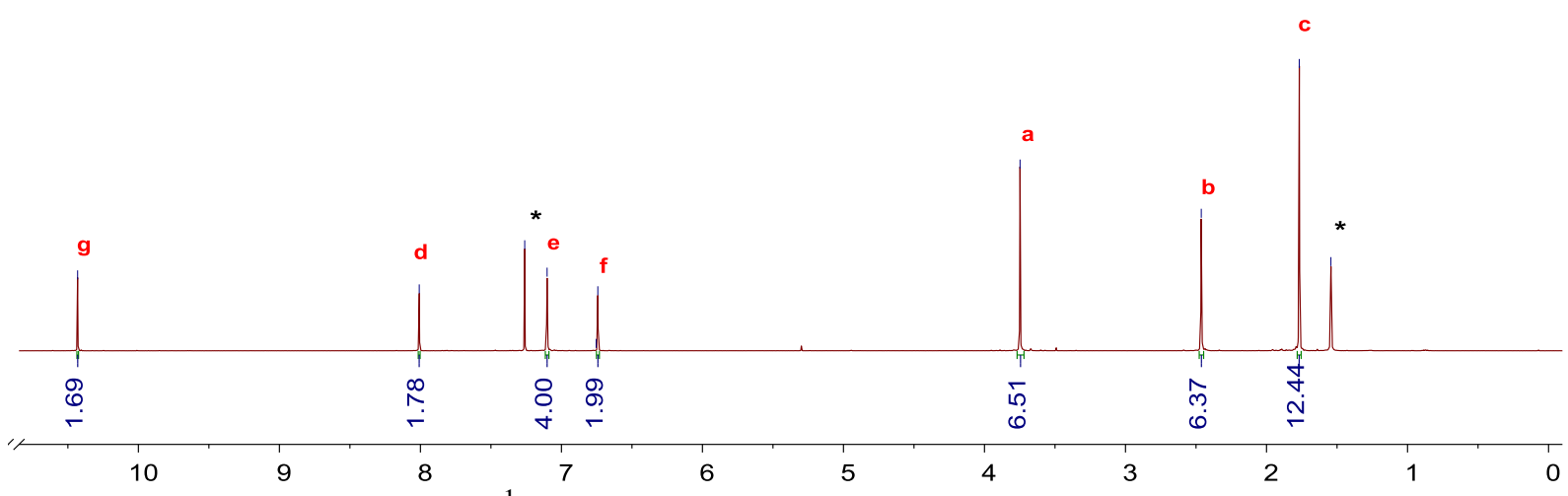

Figure S11. ${ }^{1} \mathrm{H}$ NMR spectrum of compound $3\left(\mathrm{CDCl}_{3}, \mathrm{rt}\right)$.

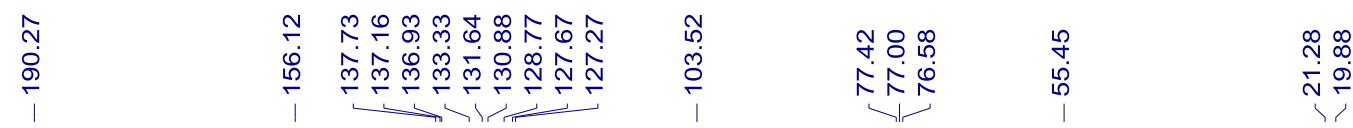<smiles>COc1cc2c(-c3c(C)cc(C)cc3C)c(-c3c(C)cc(C)cc3C)c(-c3cc(C)c(C=O)cc3C)c(-c3cc(C)cc(C)c3)c2cc1C</smiles>

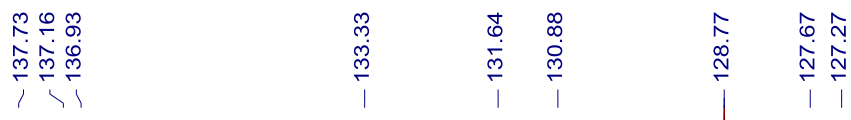
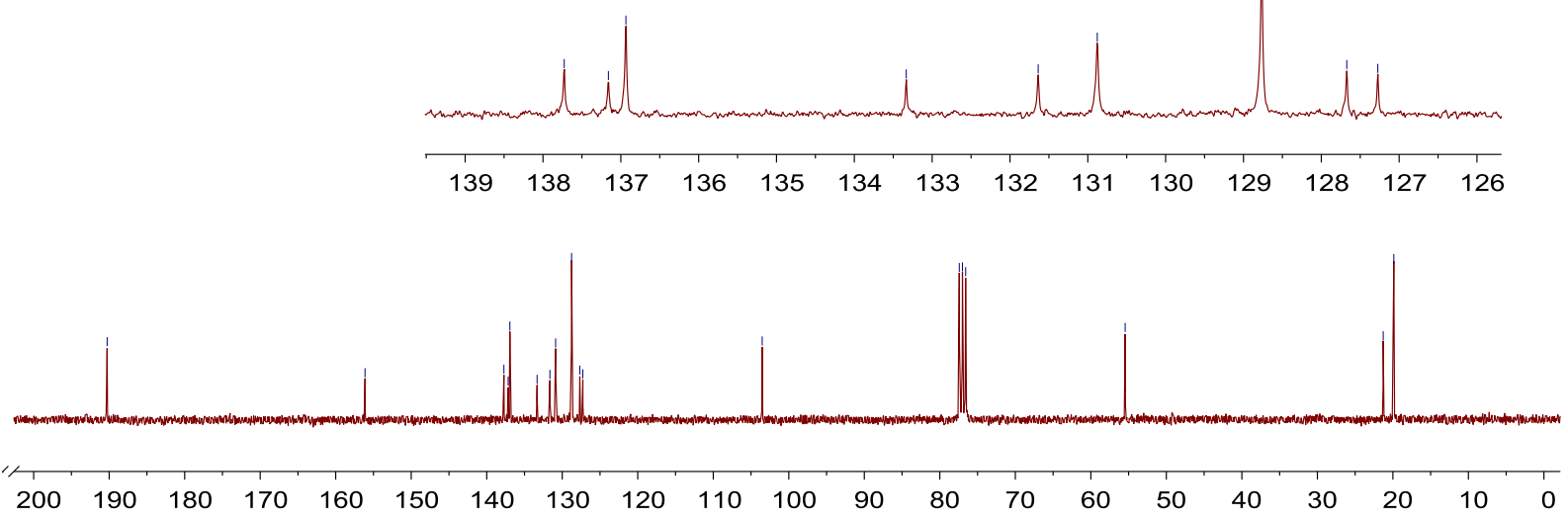

Figure S12. ${ }^{13} \mathrm{C}$ NMR spectrum of compound $3\left(\mathrm{CDCl}_{3}, \mathrm{rt}\right)$. 


\section{Mass Spectrum SmartFormula Report}

Analysis Info

Analysis Name Method

Sample Name

Comment
D:IDatalChemistry\2015 Samplel201601\0122\530-1.d YCH-150-1800.m

530

A/P Wu Jishan
Acquisition Date

Operator

Instrument / Ser\# micrOTOF-Q II 10269

\section{Acquisition Parameter}

Source Type

Focus

$\mathrm{APCl}$

Scan Begin

Not active

Scan End

$50 \mathrm{~m} / \mathrm{z}$

$1800 \mathrm{~m} / \mathrm{z}$

Ion Polarity Positive

Set Capillary $4500 \mathrm{~V}$

Set End Plate Offset $\quad-500 \mathrm{~V}$ Set Collision Cell RF $\quad 200.0$ Vpp

$\begin{array}{ll}\text { Set Nebulizer } & 3.0 \mathrm{Bar} \\ \text { Set Dry Heater } & 200{ }^{\circ} \mathrm{C} \\ \text { Set Dry Gas } & 6.0 \mathrm{I} / \mathrm{min} \\ \text { Set Divert Valve } & \text { Waste }\end{array}$

Meas. $\mathrm{m} / \mathrm{z}$ \# Formula

$\mathrm{m} / \mathrm{z}$ err [ppm] $\mathrm{rdb} \mathrm{e}^{-}$Conf $\mathrm{N}$-Rule

$531.2524 \quad 1 \quad \mathrm{C} 36 \mathrm{H} 35 \mathrm{O} 4531.2530$

$\begin{array}{rrr}1.2 & 19.5 \text { even }\end{array}$

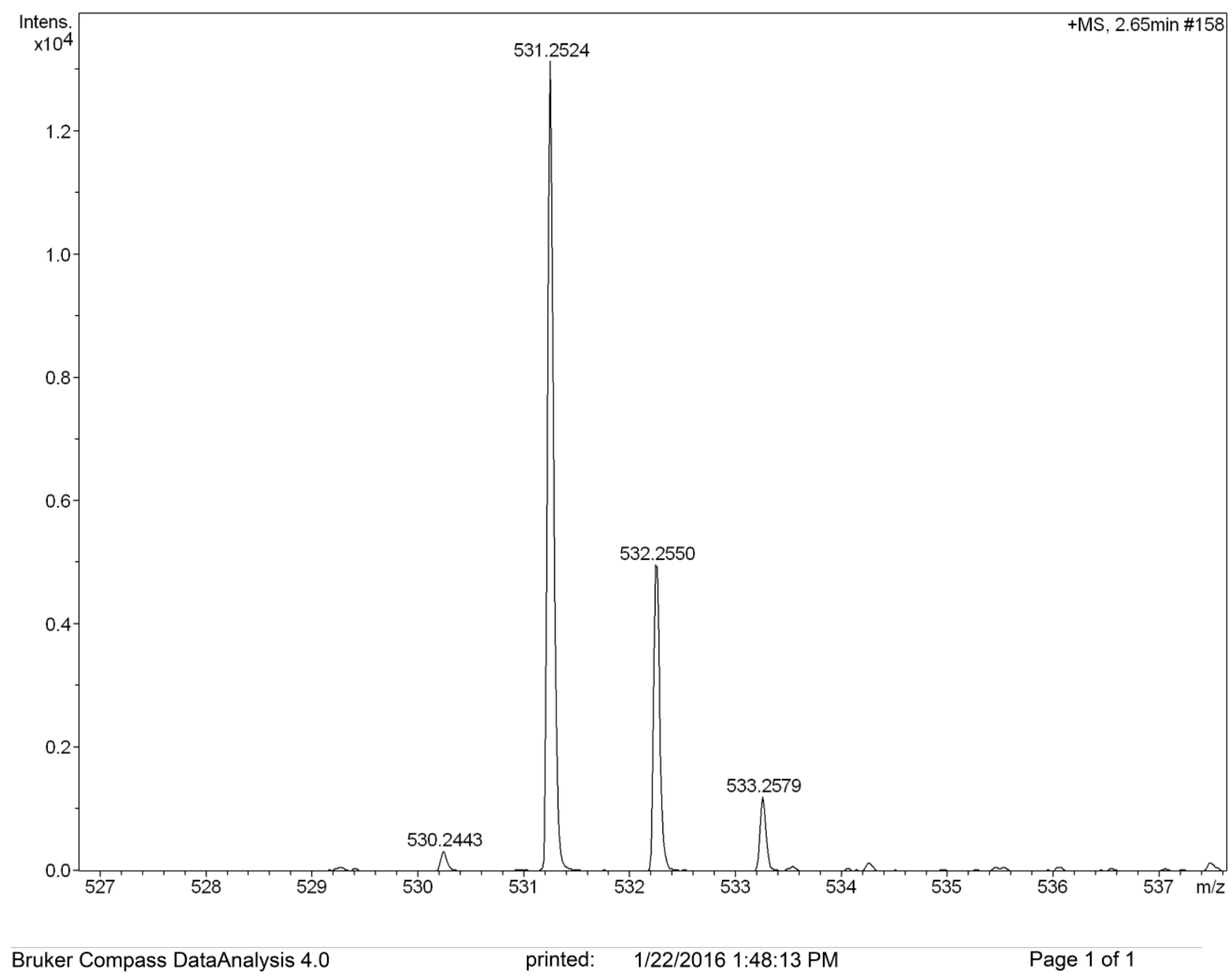

Figure S13. HR APCI mass spectrum of compound 3 . 


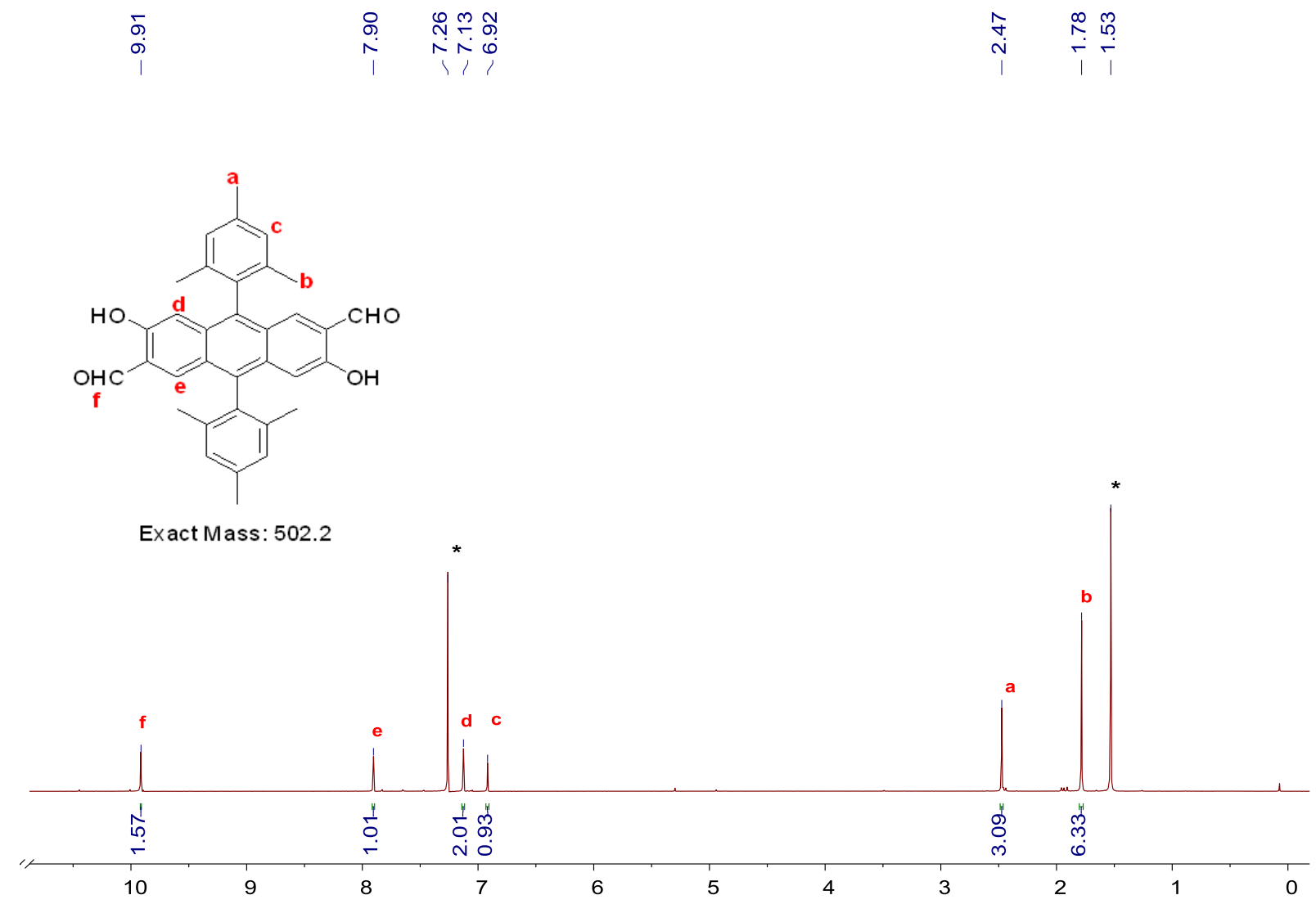

Figure S14. ${ }^{1} \mathrm{H}$ NMR spectrum of compound $4\left(\mathrm{CDCl}_{3}, \mathrm{rt}\right)$.

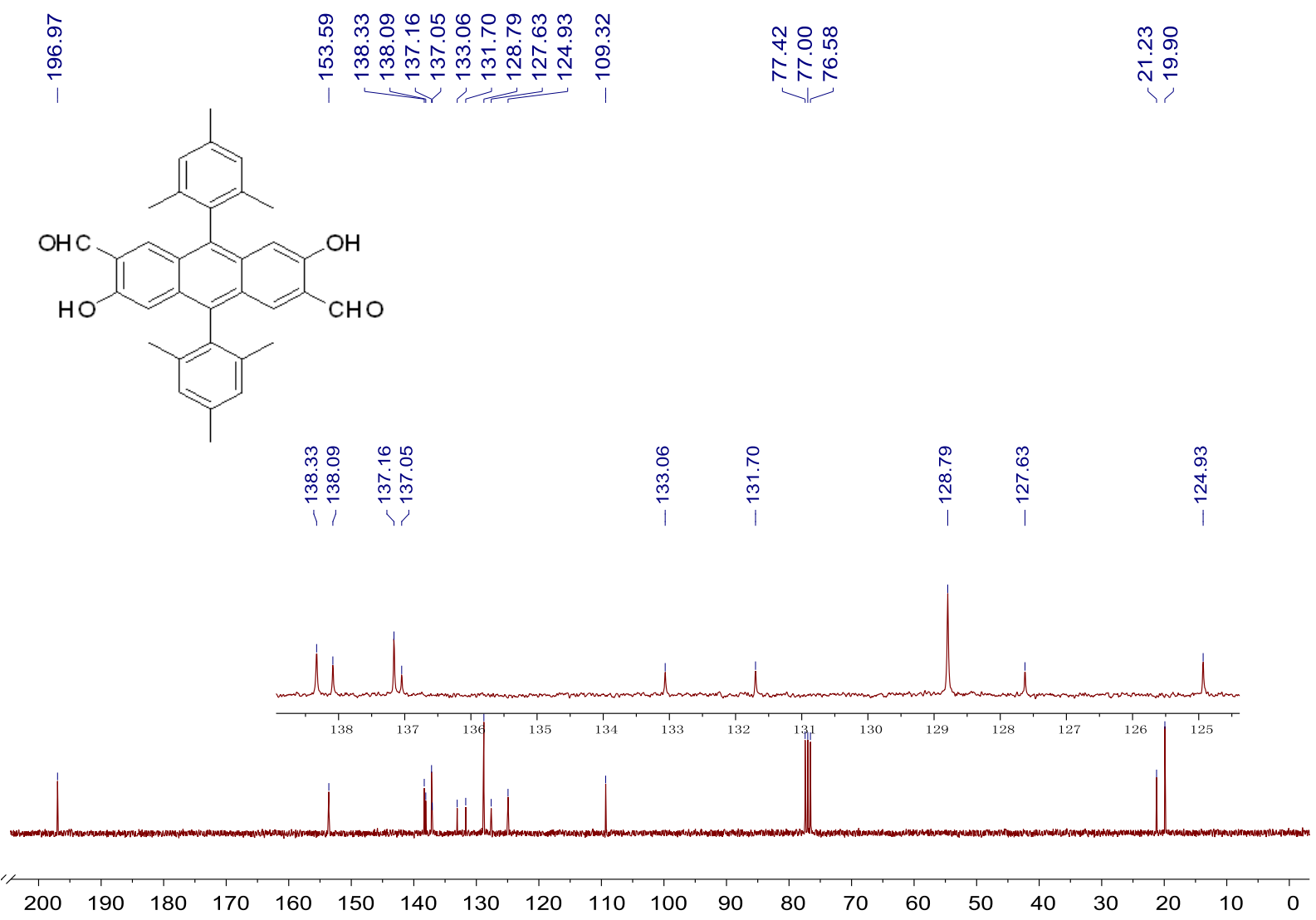

Figure S15. ${ }^{13} \mathrm{C}$ NMR spectrum of compound $4\left(\mathrm{CDCl}_{3}, \mathrm{rt}\right)$. 


\section{Mass Spectrum SmartFormula Report}

\section{Analysis Info}

Analysis Name

Method

Sample Name

Comment
Acquisition Date

1/22/2016 1:48:56 PM

Operator default user

Instrument / Ser\# micrOTOF-Q II 10269

Acquisition Parameter

Source Type

Focus Not active

Scan Begin $\quad 50 \mathrm{~m} / \mathrm{z}$

$1800 \mathrm{~m} / \mathrm{z} / \mathrm{z}$

Ion Polarity Positive

Set Capillary $4500 \mathrm{~V}$

Set End Plate Offset $\quad-500 \mathrm{~V}$

Scan End

Set Collision Cell RF $\quad 200.0$ Vpp

Set Nebulizer $\quad 3.0 \mathrm{Bar}$

Set Dry Gas $\quad 6.01 / \mathrm{min}$

Set Divert Valve Waste

Meas. $\mathrm{m} / \mathrm{z}$ \# Formula

$\mathrm{m} / \mathrm{z} \quad$ err $[\mathrm{ppm}] \quad \mathrm{rdb} \quad \mathrm{e}^{-}$Conf $\mathrm{N}-$ Rule

$503.2220 \quad 1 \quad$ C $34 \mathrm{H} 31 \mathrm{O} 4 \quad 503.2217$

-0.619 .5 even

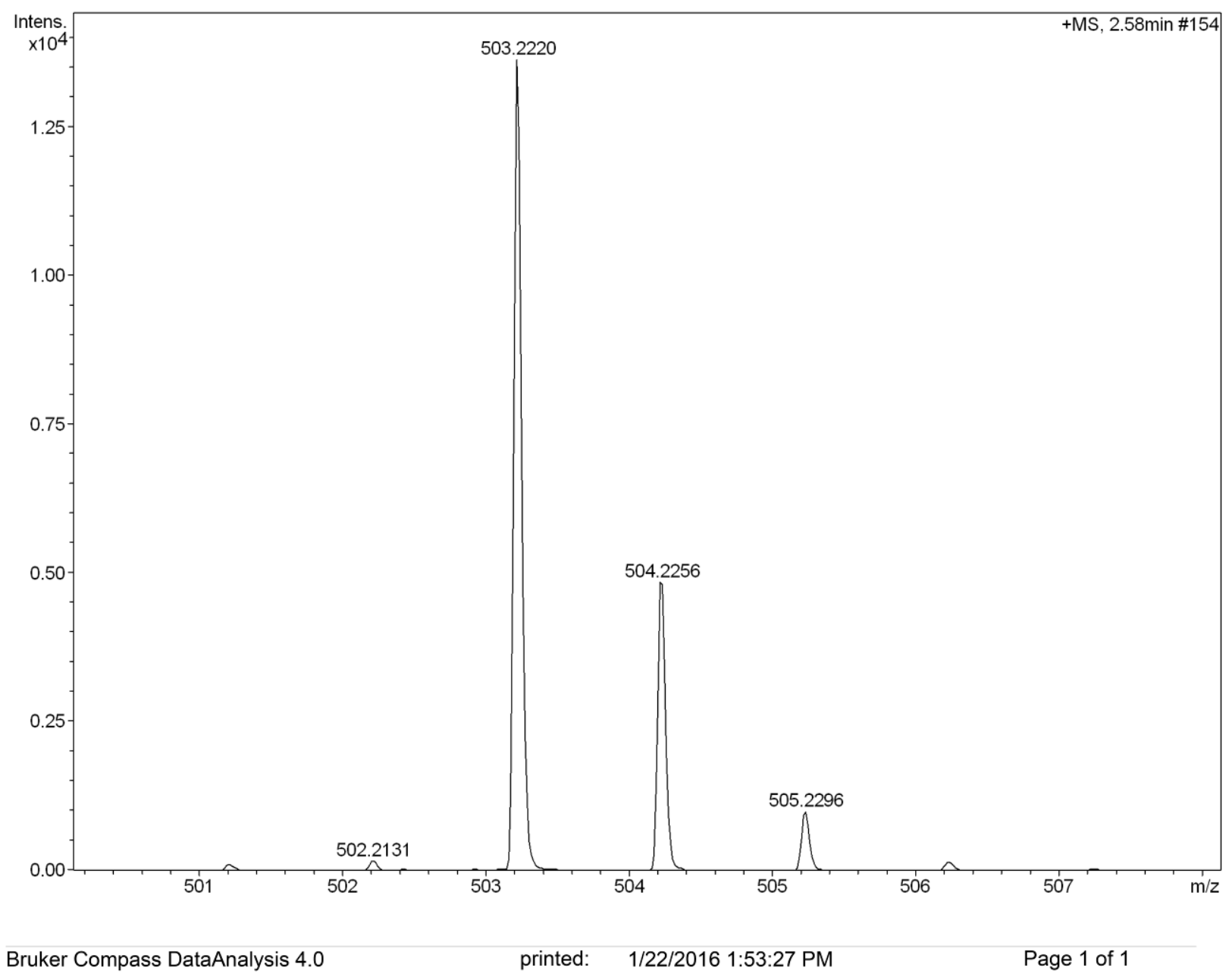

Figure S16. HR APCI mass spectrum of compound 4. 

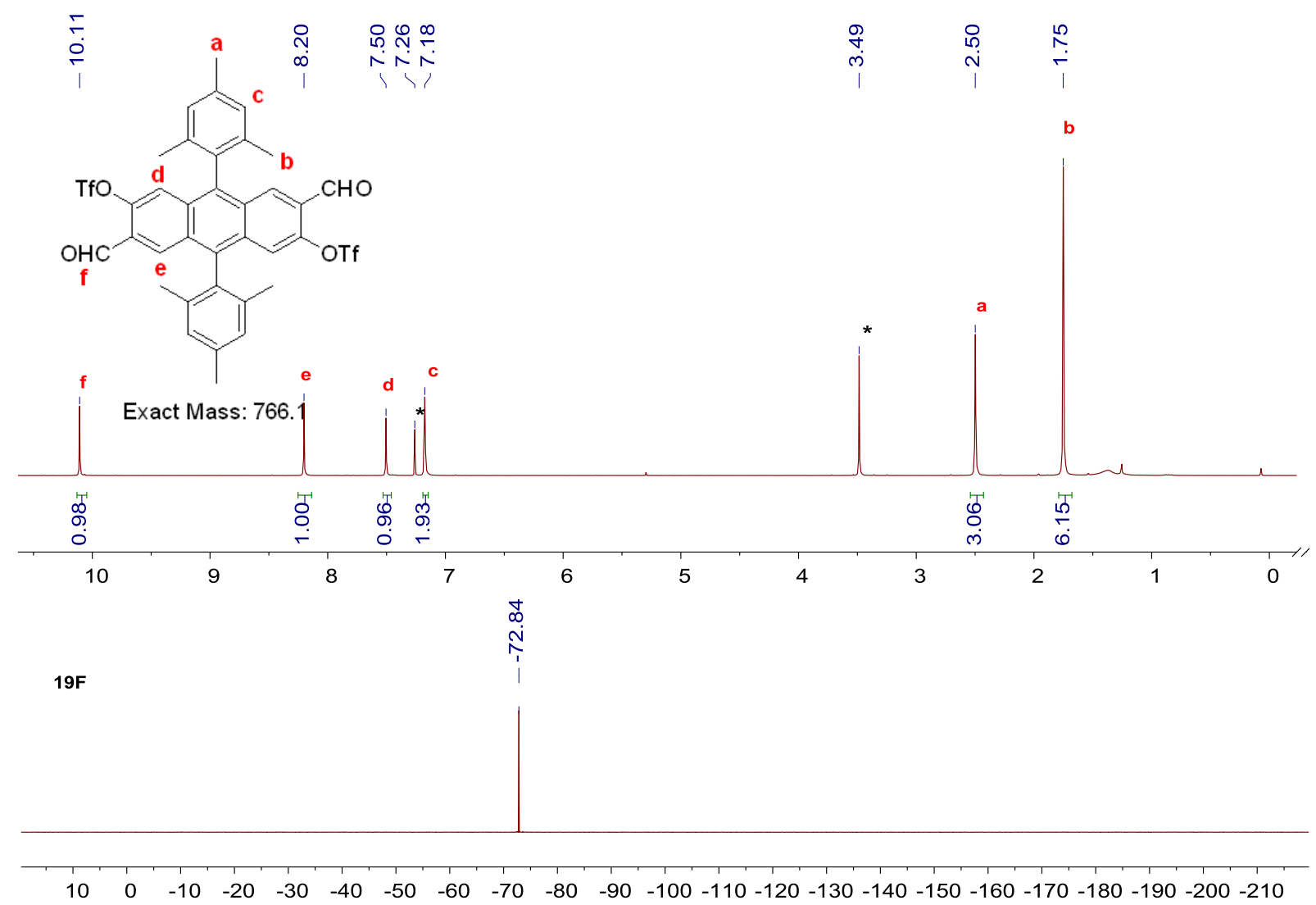

Figure S17. ${ }^{1} \mathrm{H}$ NMR and ${ }^{19} \mathrm{~F}$ NMR spectra of compound $5\left(\mathrm{CDCl}_{3}, \mathrm{rt}\right)$.

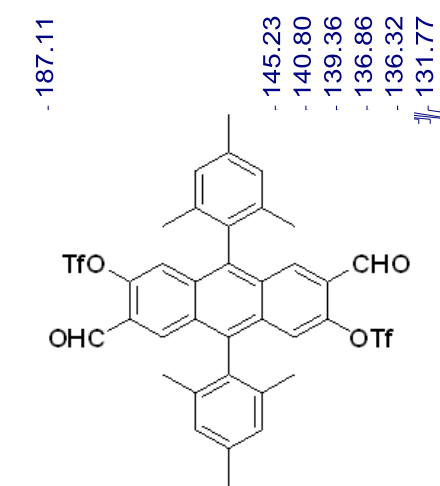

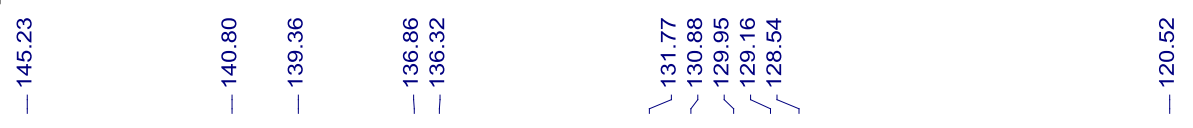

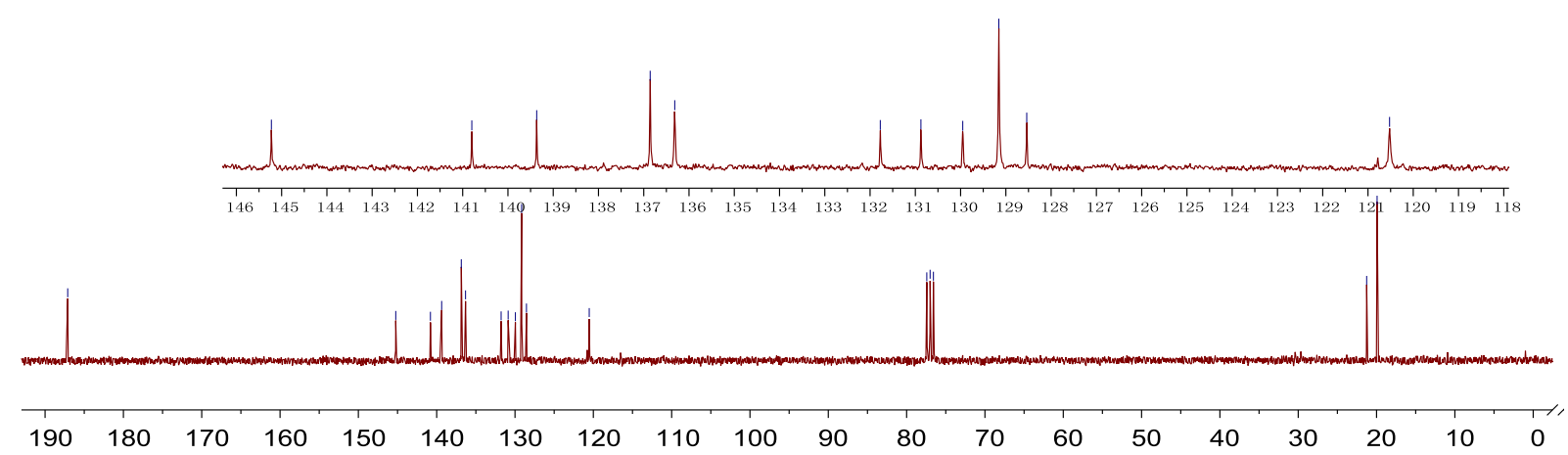

Figure S18. ${ }^{13} \mathrm{C}$ NMR spectrum of compound $5\left(\mathrm{CDCl}_{3}, \mathrm{rt}\right)$. 


\section{Mass Spectrum SmartFormula Report}

\section{Analysis Info}

Analysis Name

Method

Sample Name

Comment
Acquisition Date 1/21/2016 6:41:13 PM

Operator default user

Instrument / Ser\# micrOTOF-Q II 10269

\section{Acquisition Parameter}

Focus

D:IDatalChemistry 2015 Sample $201601 \backslash 0121-2 \backslash 766-1 . d$

YCH-150-1800.m

766

A/P Wu Jishan

$1800 \mathrm{~m} / \mathrm{z}$

\section{Ion Polarity}

Set Capillary

Set End Plate Offse

Set Collision Cell RF

Positive

$4500 \mathrm{~V}$

$-500 \mathrm{~V}$

$200.0 \mathrm{Vpp}$
Set Nebulizer $\quad 3.0 \mathrm{Bar}$

Set Dry Heater $\quad 200^{\circ} \mathrm{C}$

Set Dry Gas $\quad 6.01 / \mathrm{min}$

Set Divert Valve Waste

Meas. $\mathrm{m} / \mathrm{z}$ \# Formula $\mathrm{m} / \mathrm{z}$ err [ppm] rdb e Conf N-Rule

$\begin{array}{lllllll}767.1201 & 1 & \text { C } 36 \text { H 29 F 6 O 8 S } 2 & 767.1203 & 0.2 & 19.5 & \text { even }\end{array}$

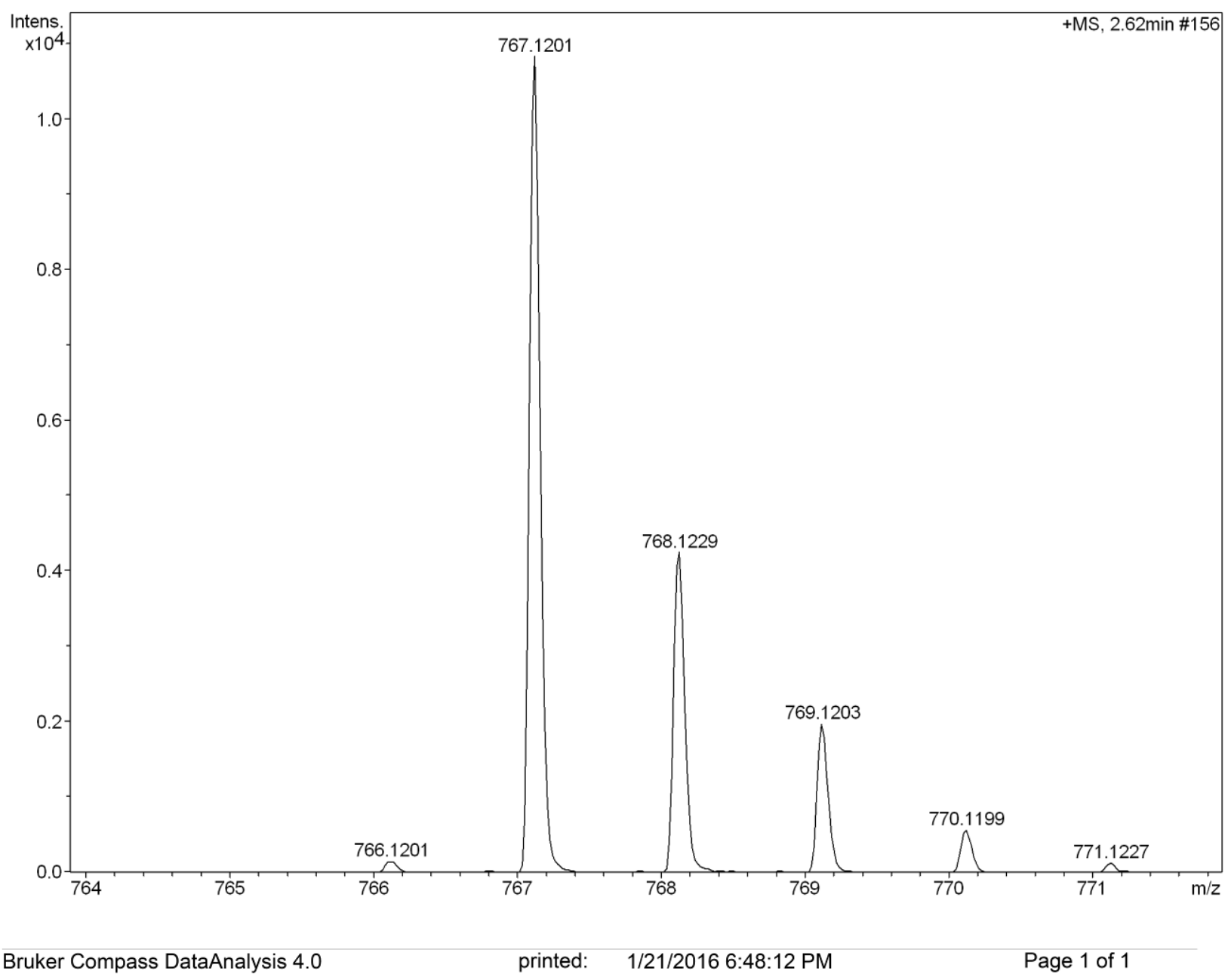

Figure S19. HR APCI mass spectrum of compound 5. 


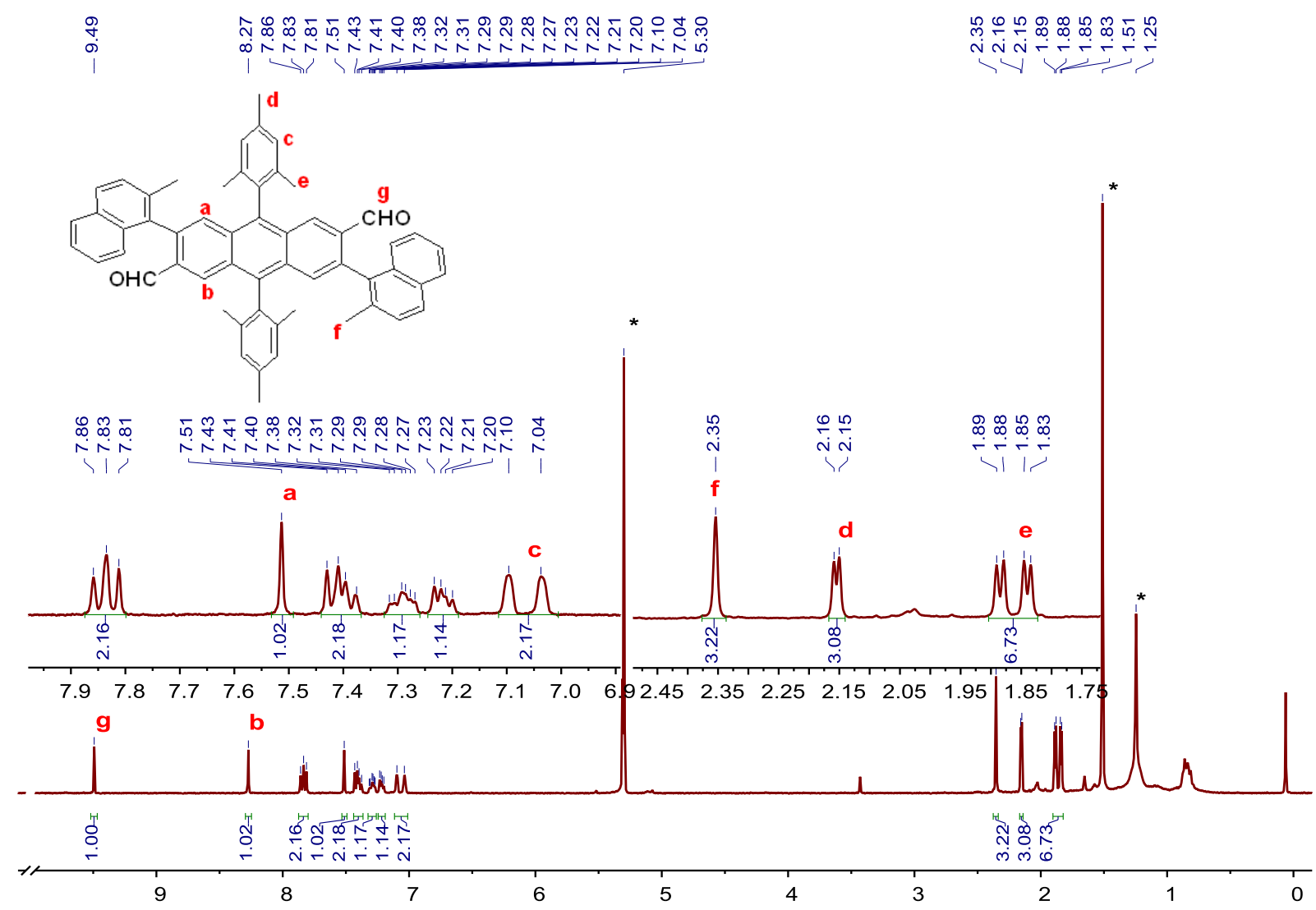

Figure S20. ${ }^{1} \mathrm{H}$ NMR spectrum of compound $6\left(\mathrm{CD}_{2} \mathrm{Cl}_{2}, \mathrm{rt}\right)$.
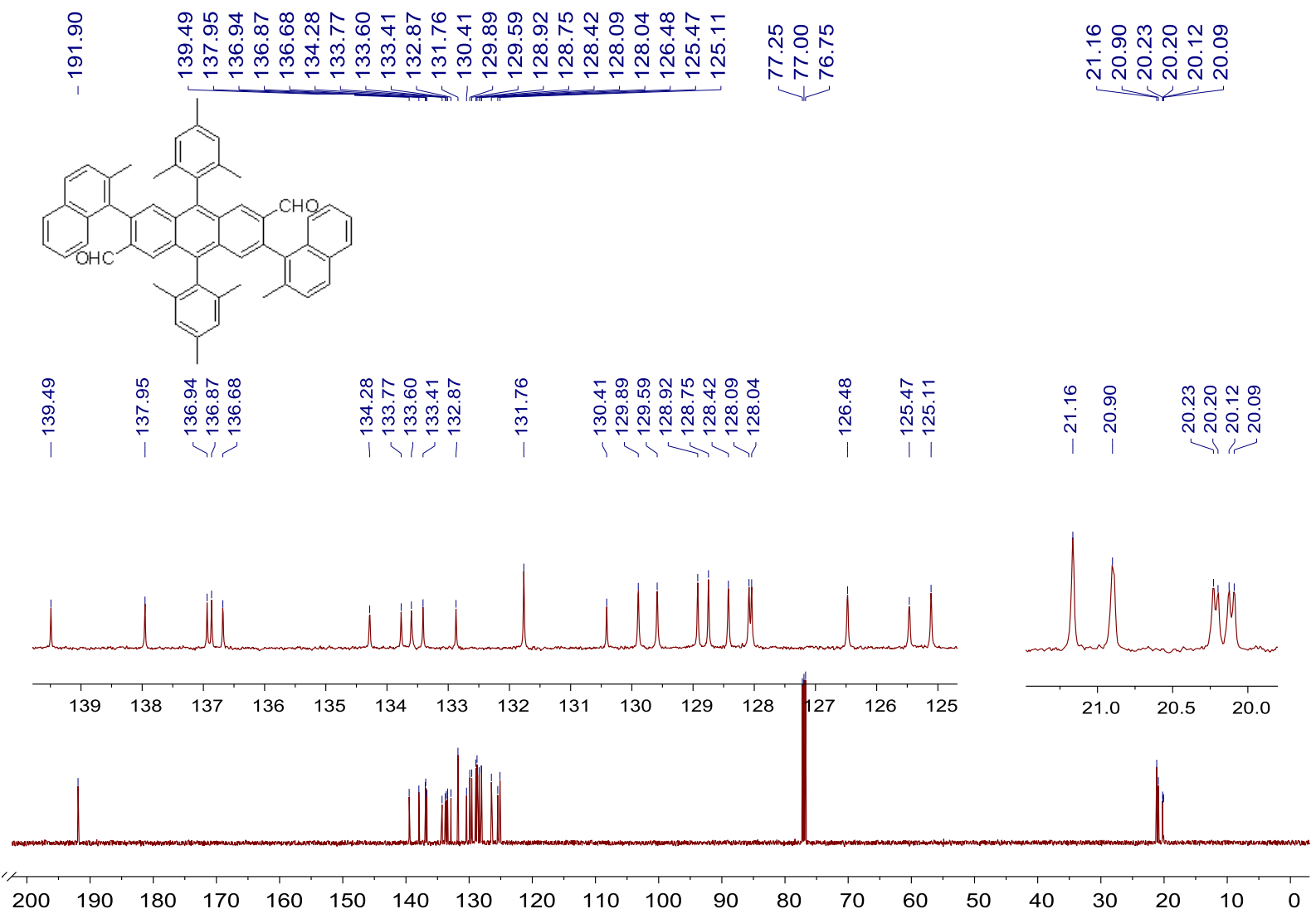

Figure S21. ${ }^{13} \mathrm{C}$ NMR spectrum of compound $6\left(\mathrm{CDCl}_{3}, \mathrm{rt}\right)$. 


\section{Mass Spectrum SmartFormula Report}

\section{Analysis Info}

Analysis Name

Method

Sample Name

Comment
Acquisition Date

Operator

1/21/2016 6:21:16 PM

D:IDatalChemistry|2015 Sample|201601।0121-2/750-1.d

YCH-150-1800.m

Instrument / Ser\# micrOTOF-Q I| 10269

A/P Wu Jishan

\section{Acquisition Parameter}

Source Type

Focus

$\mathrm{APCl}$

Scan Begin

Not active

Scan End

$50 \mathrm{~m} / \mathrm{z}$

$1800 \mathrm{~m} / \mathrm{z}$

$\begin{array}{ll}\text { Ion Polarity } & \text { Positive } \\ \text { Set Capillary } & 4500 \mathrm{~V} \\ \text { Set End Plate Offset } & -500 \mathrm{~V}\end{array}$

Set End Plate Offset $\quad-500 \mathrm{~V}$

Set Collision Cell RF $\quad 200.0$ Vpp

$\begin{array}{ll}\text { Set Nebulizer } & 3.0 \mathrm{Bar} \\ \text { Set Dry Heater } & 200{ }^{\circ} \mathrm{C} \\ \text { Set Dry Gas } & 6.0 \mathrm{l} / \mathrm{min} \\ \text { Set Divert Valve } & \text { Waste }\end{array}$

Meas. $\mathrm{m} / \mathrm{z}$ \# Formula

$\begin{array}{lll}751.3573 & 1 \mathrm{C} 56 \mathrm{H} 47 \mathrm{O} 2 & 751.3571\end{array}$

err [ppm] rdb $\mathrm{e}^{-}$Conf N-Rule

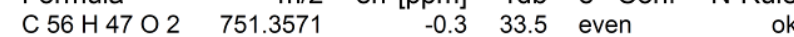

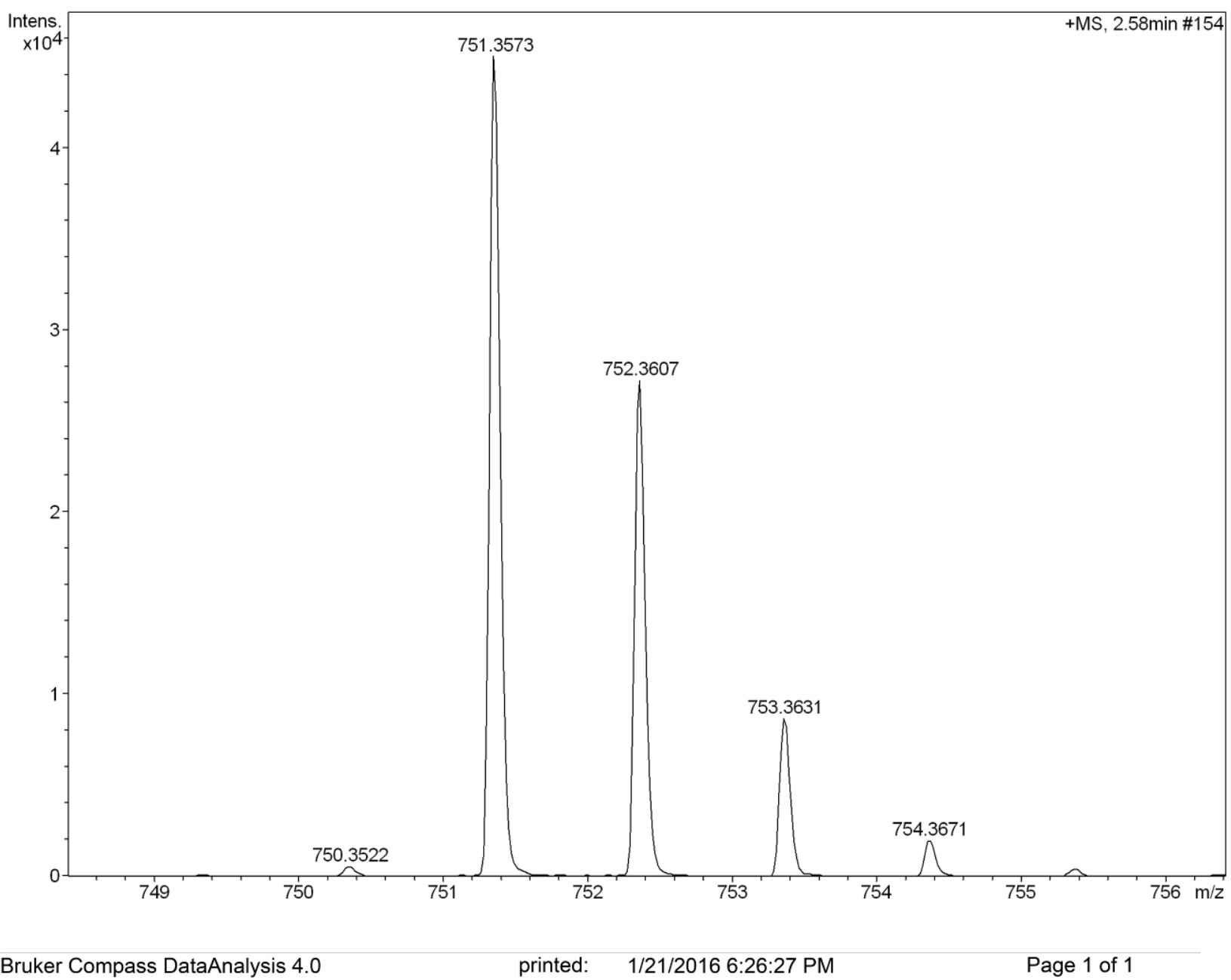

Figure S22. HR APCI mass spectrum of compound 6 . 


\section{Mass Spectrum SmartFormula Report}

Analysis Info

Analysis Name

Method

Sample Name

Comment
Acquisition Date

1/21/2016 6:27:04 PM

Operator default user YCH-150-1800.m

1142

Instrument / Ser\# micrOTOF-Q || 10269

\section{Acquisition Parameter}

Source Type

Focus

Not active

Scan Begin

Scan End

$$
50 \mathrm{~m} / \mathrm{z}
$$

$1800 \mathrm{~m} / \mathrm{z}$

$\begin{array}{ll}\text { Ion Polarity } & \text { Positive } \\ \text { Set Capillary } & 4500 \mathrm{~V} \\ \text { Set End Plate Offset } & -500 \mathrm{~V} \\ \text { Set Collision Cell RF } & 200.0 \mathrm{Vpp}\end{array}$

$\begin{array}{ll}\text { Set Nebulizer } & 3.0 \mathrm{Bar} \\ \text { Set Dry Heater } & 200^{\circ} \mathrm{C} \\ \text { Set Dry Gas } & 6.0 \mathrm{l} / \mathrm{min} \\ \text { Set Divert Valve } & \text { Waste }\end{array}$

Meas. $\mathrm{m} / \mathrm{z}$ \# Formula

err [ppm] rdb $\mathrm{e}^{-}$Conf N-Rule

$\begin{array}{llll}1143.3799 & 1 & \text { C } 72 \text { H } 51 \text { F } 12 & 1143.3794\end{array}$

$\begin{array}{lll}-0.5 & 41.5 & \text { even }\end{array}$

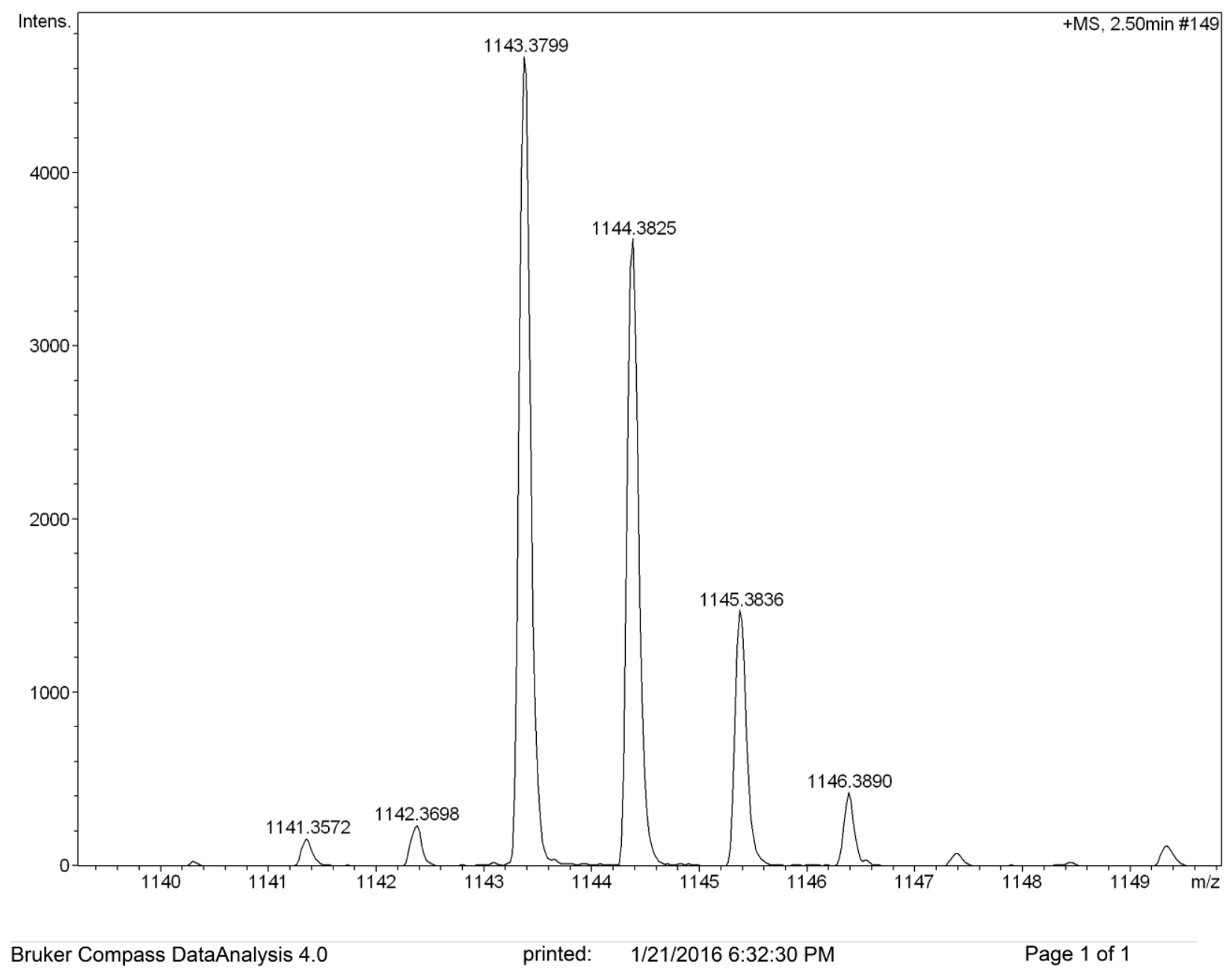

Figure S23. HR APCI mass spectrum of compound 8 . 


\section{Mass Spectrum SmartFormula Report}

Analysis Info

Analysis Name

Method

Sample Name

Comment
D:IDatalChemistry 2015 Sample $201601 \backslash 0121-2 \backslash 1140-1 . d$

$\mathrm{YCH}-150-1800 . \mathrm{m}$

1140

A/P Wu Jishan
Acquisition Date 1/21/2016 6:32:43 PM

Operator default user

Instrument / Ser\# micrOTOF-Q II 10269

\section{Acquisition Parameter}

Source Type APCI

Focus Not active

Scan Begin $\quad 50 \mathrm{~m} / \mathrm{z}$

Scan End $\quad 1800 \mathrm{~m} / \mathrm{z}$

$\begin{array}{ll}\text { Ion Polarity } & \text { Positive } \\ \text { Set Capillary } & 4500 \mathrm{~V} \\ \text { Set End Plate Offset } & -500 \mathrm{~V} \\ \text { Set Collision Cell RF } & 200.0 \mathrm{Vpp}\end{array}$

Set Nebulizer

3.0 Bar

Set Collision Cell RF

$200.0 \mathrm{Vpp}$

Set Dry Heate

Set Divert Valve Waste

Meas. $\mathrm{m} / \mathrm{z}$ \# Formula $\mathrm{m} / \mathrm{z}$ err [ppm] rdb $\mathrm{e}^{-}$Conf N-Rule

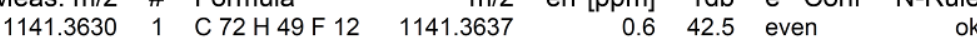

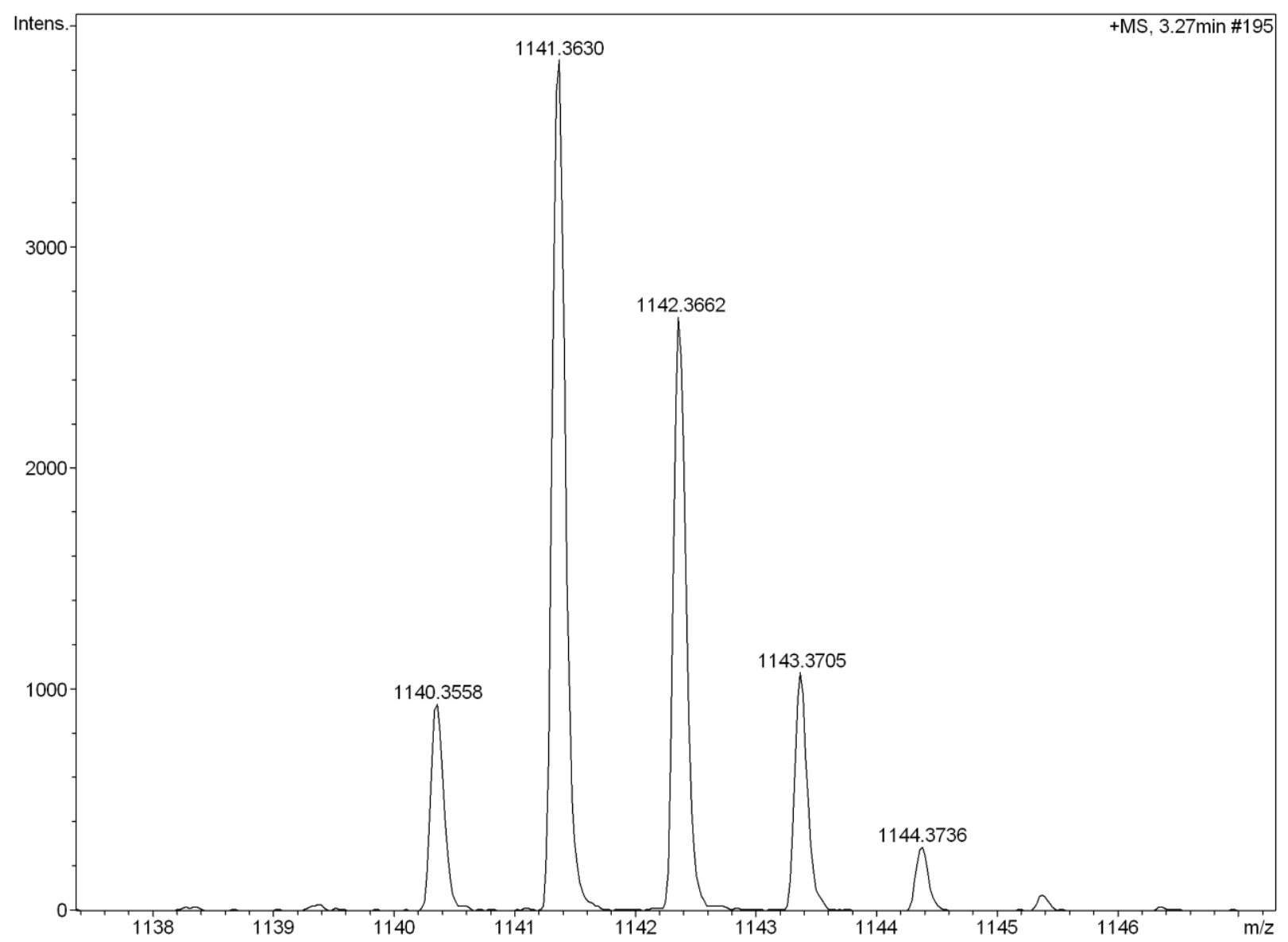

Bruker Compass DataAnalysis 4.0

printed: $\quad 1 / 21 / 20166: 40: 36 \mathrm{PM}$

Page 1 of 1

Figure S24. HR APCI mass spectrum of compound HR-NZ. 


\section{References}

[1] Bain, G. A.; Berry, J. F. J. Chem. Educ. 2008, 85, 532.

[2] Bleaney, B.; Bowers, K. D. Proc. R. Soc. London A 1952, 214, 451.

[3] Yanai, T.; Tew, D. P.; Handy, N. C. Chem. Phys. Lett. 2004, 393, 51.

[4] Hirata, S.; Head-Gordon, M. Chem. Phys. Lett. 1999, 314, 291.

[5] Becke, A. D. Phys. Rev. A 1998, 38, 3098.

[6] Lee, C.; Yang, W.; Parr, R. G. Phys. Rev. B 1998, 37, 785.

[7] Shao, Y.; Head-Gordon, M.; Krylov, A. I. J. Chem. Phys. 2003, 118, 4807.

[8] Frisch, M. J.; Trucks, G. W.; Schlegel, H. B.; Scuseria, G. E.; Robb, M. A.; Cheeseman, J. R.; Scalmani, G.; Barone, V.; Mennucci, B.; Petersson, G. A.; Nakatsuji, H.; Caricato, M.; Li, X.; Hratchian, H. P.; Izmaylov, A. F.; Bloino, J.; Zheng, G.; Sonnenberg, J. L.; Hada, M.; Ehara, M.; Toyota, K.; Fukuda, R.; Hasegawa, J.; Ishida, M.; Nakajima, T.; Honda, Y.; Kitao, O.; Nakai, H.; Vreven, T.; Montgomery Jr., J. A.; Peralta, J. E.; Ogliaro, F.; Bearpark, M. J.; Heyd, J.; Brothers, E. N.; Kudin, K. N.; Staroverov, V. N.; Kobayashi, R.; Normand, J.; Raghavachari, K.; Rendell, A. P.; Burant, J. C.; Iyengar, S. S.; Tomasi, J.; Cossi, M.; Rega, N.; Millam, N. J.; Klene, M.; Knox, J. E.; Cross, J. B.; Bakken, V.; Adamo, C.; Jaramillo, J.; Gomperts, R.; Stratmann, R. E.; Yazyev, O.; Austin, A. J.; Cammi, R.; Pomelli, C.; Ochterski, J. W.; Martin, R. L.; Morokuma, K.; Zakrzewski, V. G.; Voth, G. A.; Salvador, P.; Dannenberg, J. J.; Dapprich, S.; Daniels, A. D.; Farkas, Ö.; Foresman, J. B.; Ortiz, J. V.; Cioslowski J.; Fox, D. J. Gaussian 09, Gaussian, Inc., Wallingford, CT, USA, 2009.

[9] Shao, Y.; Gan, Z.; Epifanovsky, E.; Gilbert, A.T.B.; Wormit, M.; Kussmann, J.; Lange, A.W.; Behn, A.; Deng, J.; Feng, X.; Ghosh, D.; Goldey, M.; Horn, P.R.; Jacobson, L.D.; Kaliman, I.; Khaliullin, R.Z.; Kus, T.; Landau, A.; Liu, J.; Proynov, E.I.; Rhee, Y.M.; Richard, R.M.; Rohrdanz, M.A.; Steele, R.P.; Sundstrom, E.J.; Woodcock III, H.L.; Zimmerman, P.M.; Zuev, D.; Albrecht, B.; Alguires, E.; Austin, B.; Beran, G.J.O.; Bernard, Y.A.; Berquist, E.; Brandhorst, K.; Bravaya, K.B.; Brown, S.T.; Casanova, D.; Chang, C.-M.; Chen, Y.; Chien, S.H.; Closser, K.D.; Crittenden, D.L.; Diedenhofen, M.; DiStasio Jr., R.A.; Do, H.; Dutoi, A.D.; Edgar, R.G.; Fatehi, S.; Fusti-Molnar, L.; Ghysels, A.; Golubeva-Zadorozhnaya, A.; Gomes, J.; Hanson-Heine, M.W.D.; Harbach, P.H.P.; Hauser, A.W.; Hohenstein, E.G.; Holden, Z.C.; Jagau, T.-C.; Ji, H.; Kaduk, B.; Khistyaev, K.; Kim, J.; Kim, J.; King, R.A.; Klunzinger, P.; Kosenkov, D.; Kowalczyk, T.; Krauter, C.M.; Laog, K.U.; Laurent, A.; Lawler, K.V.; Levchenko, S.V.; Lin, C.Y.; Liu, F.; Livshits, E.; Lochan, R.C.; Luenser, A.; Manohar, P.; Manzer, S.F.; Mao, S.-P.; Mardirossian, N.; Marenich, A.V.; Maurer, S.A.; Mayhall, N.J.; Oana, C.M.; Olivares-Amaya, R.; O’Neill, D.P.; Parkhill, J.A.; Perrine, T.M.; Peverati, R.; Pieniazek, P.A.; Prociuk, A.; Rehn, D.R.; Rosta, E.; Russ, N.J.; Sergueev, N.; Sharada, S.M.; Sharmaa, S.; Small, D.W.; Sodt, A.; Stein, T.; Stuck, D.; Su, Y.-C.; Thom, A.J.W.; Tsuchimochi, T.; Vogt, L.; Vydrov, O.; Wang, T.; Watson, M.A.; Wenzel, J.; White, A.; Williams, C.F.; Vanovschi, V.; Yeganeh, S.; Yost, S.R.; You, Z.-Q.; Zhang, I.Y.; Zhang, X.; Zhou, Y.; Brooks, B.R.; Chan, G.K.L.; Chipman, D.M.; Cramer, C.J.; Goddard III, W.A.; Gordon, M.S.; Hehre, W.J.; Klamt, A.; Schaefer III, H.F.; Schmidt, M.W.; Sherrill, C.D.; Truhlar, D.G.; Warshel, A.; Xu, X.; Aspuru-Guzik, A.; Baer, R.; Bell, A.T.; Besley, N.A.; Chai, J.-D.; Dreuw, A.; Dunietz, B.D.; Furlani, T.R.; Gwaltney, S.R.; Hsu, C.-P.; Jung, Y.; Kong, J.; Lambrecht, D.S.; Liang, W.Z.; Ochsenfeld, C.; Rassolov, V.A.; Slipchenko, L.V.; Subotnik, J.E.; Van Voorhis, T.; Herbert, J.M.; Krylov, A.I.; Gill, P.M.W.; Head-Gordon, M. Mol. Phys., 2015, 113, 184.

[10] Luzanov, A. V.; Casanova, D.; Feng, X.; Krylov, A. I. J. Chem. Phys. 2015, 142, 224104.

[11] Casanova, D.; Krylov, A. I. J. Chem. Phys. 2016, 144, 014102. 